\title{
Megtestesülés és megtestesítés: néző, színpad és színész a koramodern színházban
}

\begin{abstract}
Absztrakt
A dolgozat koramodern drámai testmetaforák elemzésével vizsgálja, hogyan alakul a közönség és a szereplôk szelfrôl alkotott képe a drámaszöveg, színrevitel és a közönség színházi élményének interakciója nyomán kibomló térérzékelés során. Miközben azt vizsgálja, hogyan képesek térbeli elemek alakítani a szubjektumot, különös figyelmet szentel a térbeli penetráció kérdésének, amely egy bizonyos karakter belsô énjébe, tudatába való bejutás összetett ábrázolására képes. A dolgozat elméleti keretének megalkotásában fontos szerep jut a tér szociális érzékelésével foglalkozó elméletírók (Hall, Lefebvre) munkáinak, lehetôvé téve a propriocepcióval kapcsolatos analízis színpadra való alkalmazását a közönség-színpad viszonyában. Az elemzett darabok között szerepelnek Shakespeare kortársak darabjai (Bussy D’Amboise; Kár, hogy kurva; Amalfi hercegnố) és Shakespeare darabok is (Romeo és Júlia, Coriolanus).
\end{abstract}

\section{Szerzó}

Jennifer A. Low a Florida Atlantic University angol tanszékének professzora, Shakespeare-t, reneszánsz irodalmat és modern drámát tanít. Különösen érdeklik a múlt és a jelen színházak szcenográfiai megoldásai. Monográfiáiban foglalkozott a maszkulinitás koramodern kialakulásával (Manhood and the Duel: Masculinity in Early Modern Drama and Culture, Palgrave, 2003) és a drámai terek nézôi észlelésének kérdésével (Dramatic Spaces: Scenography and Spectatorial Perceptions, Routledge, 2015), újabban pedig Gordon Craig illusztrált Hamlet-kiadását kutatja.

https://doi.org/10.31176/apertura.2017.12.4.2 


\section{Megtestesülés és megtestesítés: néző, színpad és színész a koramodern színházban}

Képzeljük el a következô, haláltusát ábrázoló jelenet eredeti színrevitelét: [1]

A Bussy D’Ambois címszereplôje először sikeresen legyőzi a mindenre elszánt bérgyilkosokat, majd párharcra hívja azok megbízóját. Ellenségét legyôzvén éppen megkönyörülne rajta, amikor egy színpadon kívüli orgyilkos pisztolylövése végez vele. Elcsodálkozva azon, hogy az ô teste sem több, mint áthatolható, sérülékeny húsdarab, Bussy megesküszik, hogy Vespasianus császárhoz hasonlóan állva fogja várni a halált, majd megszólítja kardját: „Légy újra támaszom, hú penge, ahogyan eddig is tetted! / Élet és halál - e két gondolat mindig is egyenlő súlyként nehezedett rám s így nem billenhettem el. / Akár egy dicsô, római szobor, úgy állok most itt. S állni is fogok mindaddig, míg a halál testemet hûvös márvánnyá nem merevíti. / Élj tovább, ó hírnevem, a gyilkosság árnya ne burkoljon homályba" (5.4.78,93-98). ${ }^{[2]}$ Ezzel szemben a Romeo és Júlia fôhoósnôje feleszmél ravatalán, hogy Lôrinc atya Romeo holttestére vetett gyászos pillantásaiból rájöjjön: „Mindnyájunknál hatalmasabb erô / Áthúzta számításomat”. Az atya szinte rögtön magára hagyja Júliát, aki - öngyilkossága véghezviteléhez megfelelô eszközt keresve - rátalál Romeo tôrére: „Jönnek! / De nem késem! - Jer, drága tôr: (Kirántja Romeo tốrét) / Ez jobb hüvely (Keblébe döfi) - / maradj itt mindörökre" (5.3.153-54). ${ }^{[2]}$

Bussy nyilvános halált hal - Monsieur és Guise felülrôl figyelik ốt - és végsố monológjában benne rejlik a társadalmi pozíciójával kapcsolatos aggodalma, melynek nagyobb jelentôséget tulajdonít magánéleténél. A cselekmény hangsúlyossá teszi a sebesült, ugyanakkor szilárdan álló testet, amely - a háttérben torlódó gyilkos tömeg miatt -szükségszerúen a színpad elôterében helyezkedik el; ehhez hasonlóan a Montsurryvel való viadal is megkövetelte, hogy a fôhôs közel legyen a színtér centrumához. Habár Bussyt többen is körülveszik, mind ellensége, mind a bérgyilkosok ügyelnek, hogy a kardjától megfelelô távolságot tartsanak. Montsurry arckifejezése - miközben haragosa haláltusáját nézi - a közönség Bussy sérülése iránti érdeklődését tükrözi. Tamyra és a szerzetes árnyéka megzavarhatja a drámai képet, vagy éppen erôsítheti is azáltal, hogy a fôhôs haláláig zavartalanul állva maradhat. A közönség bevonódását két extradramatikus fogás is befolyásolhatta: erôsítette a Szent Pál katedrális színpadához való fizikai közelségük, és gyengítette az a tény, hogy a szereplók gyermekek voltak: a Szent Pál katedrális gyermekszínészei.

A Lordkamarás Emberei majdnem egy évtizeddel korábban a Romeo és Júliát közszínpadon mutatták be. A színpadi utasítások által számtalanszor megemlített kriptaként az öltözőház funkcionált, amely a színpad hátsó részében húzódott ${ }^{[3]}$; emiatt a nézôk akár arra is 
kényszerülhettek, hogy erôsen hunyorítsanak vagy előredőljenek, annak érdekében, hogy kivehessék Júlia mozdulatait a sötét helyiségben. Leszámítva a sírkamrában fekvô Romeo és a küszöbön elterülő Paris holttestét, Júlia magányosan vetett véget életének. Ennek a fókusznak a segítségével hangsúlyossá válhatott a szúkülô perspektíva, melyet a távolság és a részletek finom összhangja eredményezett: egy jelentôségteljes, de nem látványos mozdulat megjelenítése egy vizuálisan letisztult térben, távol a közönségtôl. Ez a fajta színrevitel magába szippantotta a nézôket; a közönség azáltal vonódott be, hogy kénytelen volt feszülten követni az eseményeket.

Mindkét fentebb összefoglalt részlet keretbe foglalja a haláltusát. Bussy szenvedését az ôt körülvevő bámész tömeg szegélyezi, tükrözve egyúttal a közönség nézôi bevonódását. A keret az agónia helyszínét tekintve is tetten érhető, hiszen Tamyra apró szobája, ahol a csapóajtóból felemelkedô Bussyt és a szerzetest fogadta, mimetikusan (bár a vizualitást mellôzve) zárja magába a haldoklás jelenetét. Ebben a szükségszerú megvalósításban Chapman vizuális paradoxon iránti vonzódása érhetô tetten. Bussy halálát illetôen minden a nyilvánosságot hangsúlyozza: a hírnévvel kapcsolatos aggodalmai, a fentrốl bámészkodók és az érintőlegesen szerepeltetett bérgyilkosok jelenléte, a fôhốs eltökélt ragaszkodása, hogy állva várja a vég eljövetelét (ki mást kívánhat ezzel lenyúgözni, mint azokat, akik nézik?). Mégis, az egész egy privát térben zajlik, ott, ahol Tamyra szeretôjével szerelmi afférba, férjével pedig bizalmas beszélgetésekbe bonyolódott. ${ }^{[4]}$ Bussy teátrális halála által Tamyra szobája a látvány terévé változik, hôsies tettének végsô színhelyévé. A képzeletbeli térnek viszont nem csak a funkciója változik meg, Bussy annak a határait is kijjebb tolja: ellenségei körgyưrújében állva keretbe zárja a hôst, ô azonban szavaival kitágítja azt, kiterjesztve Tamyra szobáját a Szent Pál katedrális egész terére. (A Blackfriars színház pódiumánál a Szent Pál jelentôsen kisebb méretekkel bírt: a húsz méter hosszúságú elóadóteremben lévô meglehetôsen keskeny színpad szélessége alig haladta meg a hat métert.) ${ }^{[5]}$

A haláltusa jelenete miatt Chapman nem szégyenkezhet: a történetnek egy nagyon bensőséges térben vet véget, mely hatásosan múködött a szintén meghitt magánszínház pódiumán [6]; megengedi ugyanakkor Bussy-nak azokat a retorikai fogásokat, amelyekkel szónoki emelvénnyé változtatja Tamyra szobáját. Míg a fôhőst a helyszín és a színrevitel módja is elkülönítik a többiektôl, addig elôadásmódja egyszerre emlékezteti a közönséget annak kollektív jellegére és arra, hogy az ô nézôi tekintetük által dicsőülhet meg, és kerülheti el, hogy megmaradjon egyszerú elégedetlenkedônek vagy ágyasnak. Bussy az iránti vágya, hogy a halál „húvös márvánnyá merevítse [ôt]" [7] a szilárdan álló szobrok állandóságát eleveníti föl, párhuzamosan megidézve az emlékmú függóleges és a sírkő faragott képmásának vízszintes terét. Ezáltal a helyszín Bussy hôsiességre való törekvésének metaszínházi fórumává válik: retorikailag annak felel meg, amikor a modern színpad elsötétül, és csak a monologizáló fôhoosre vetül reflektorfény.

Júlia agóniája ugyancsak keretes szerkezetú, a jelenet struktúráját a kripta helyszíne és annak színpadi megfelelôje, az öltözóház teremtik meg. Shakespeare, Romeo alakját használva, számtalan módon igyekszik hangsúlyozni a tér klausztrofób jellegét; a legsokatmondóbb részletek között szerepel, hogy a türelmetlen Romeo csákánnyal és feszítôvassal esik neki az ajtónak (5.3.22 és 48 s.d.); ilyen funkciójú a Halál felelevenítése, mint szörnyúséges Ámor, aki újrajátssza a mitikus 
hálószoba-jelenetet a Pszichéként értelmezhetô Júliával (vagy éppen Romeóval); a sír élethú megidézése az ifjú keserú szavai által: „hol síri férgek szolgalányaid” (5.3.22). A freudi interpretáció szerint ez a Liebestod az anyaméhbe való visszatérést szimbolizálja. ${ }^{[8]}$ Romeo hazaindul Veronába, és tulajdonképpen eltemeti magát, az utolsó mozdulata pedig egy orgazmusszerú csók. Júlia szinte önkívületi állapotban szíven szúrja magát; a mú eredeti verziójában neki is, csakúgy, mint szerelmének, a die [meghal] a végsô szava, melynek nyilvánvaló a kétértelmúsége. ${ }^{\left[{ }^{9]}\right.}$ Júlia teste - a lány utolsó, öngyilkos mozdulata által - szimbolikusan hüvellyé változik, melybe Romeo tôre behatol. Bimbózó termékenységének kelyhe így csak a halálnak ad otthont.

Mindkét haláljelenet sokkal inkább árnyalja a halál helyszínének jellegét, mint ahogy ez egy átlagos színpadképpel történik. Bussy monológja kiterjeszti a fikciós teret, melyben a fôhôs végül a halálát leli: Júlia kriptája a lány testét szimbolizálja. Anne Ubersfeld elméletíró a következôképpen vélekedik a tér szerepérôl:

A konkrét kapcsolatrendszerek sokasága révén a színpadi tér szimultán képes közvetíteni egy metaforikus hálót, egy szemantikai síkot és egy aktanciális [aktiváló vagy energizáló] modellt... Hasonlóképpen, amennyiben a színpadi tér egyszerre képes megjeleníteni egy adott szöveget, egy szociokulturális vagy szociopolitikai kapcsolatrendszert vagy éppen az elme topográfiáját, akkor biztosak lehetünk abban, hogy a különbözô formateremtô struktúrák között számos áthallás múködik. [10]

A behatolás Júlia testébe képileg (együttlét) és metaforikusan (öngyilkosság módja) egyaránt tematizálódott; a penetrációt azonban leginkább talán a fiú sírkamrába való betörése érzékelteti. Romeo a Capulet família házába és tagjai közé is erôszakosan jutott be; ezúttal a dinasztia egy újabb erôdjét készült megostromolni: a családi kriptát. Ezek a családot alkotó struktúrák - Júlia testét is beleértve - a fiú végső, ôrjöngésbe hajló behatolásában összpontosulnak. Késôbb, ahogy Júlia szíven szúrja magát, akaratlanul is megismétli az erôszakot. Ugyanez a szimbolizmuson alapuló struktúra jelenik meg a Bussy D’Ambois esetében is, itt azonban Bussy halálával végződik. A fôhôs mindig egy csapóajtóba torkolló titkos folyosón keresztül jutott be Tamyra szobájába, számtalan közös randevújuk helyszínére; ez a rejtett átjáró - a klasszikus freudista megközelítések szerint legalábbis - a vagina helyettesítôjeként funkcionál. Tamyra a darab során mindenféle lehetséges módon elzárkózott a férje elól, visszautasítva, hogy információkat osszon meg vele, még akkor is, mikor a férfi rátámadt és megkínozta; ezzel szemben szeretójéhez mindig nyíltan fordult, s nem volt rest elsô randevújukat egy átlátszó fortéllyal biztosítani:

És ô, kit szívembe fogadtam, majd undorral fordul felém / Mikor szélnek eresztem vágyam, erényem s hírnevem / Hogy egy ismeretlen karjaiban csorduljak el. / Nézd, nézd, feltárul hát az ajtó, mely láthatatlanul / Megbújt eddig férjem s mások szeme elôtt, de /Kinyílt nekem, s neki, ki tálcán hozza elém kedvesem.

$(2.2 .124-29)$ 
Az „ajtó”, amelyet megemlít, szó szerint arra az emelô gépezetre utal, amelyen keresztül Bussy és a szerzetes az alsóbb szinten lévő pincéból Tamyra szobájába juthatott. Ezen a ponton azonban Freud cserben hagy minket: habár erôs a késztetés, hogy a rejtett átjárót a nôi genitália szimbólumaként értelmezzük, semmi sem utal arra, hogy Tamyra megtagadta volna férjétôl a testi együttlétet. Az átjárónak így egy sokkal szofisztikáltabb jelentés tulajdonítható: a nô személyiségének egy olyan része, mely a világ elôtt rejtett maradt, és ahová csak a gyóntató papja nyerhetett bepillantást. Annak ellenére, hogy Tamyra testének hozzáférhetôségét többször is fókuszba helyezi a mú, az igazi hangsúly a nô szubjektivitásán van. ${ }^{[1]]}$ Ahogy a Romeo és Júlia esetében is, a darab a fikciós teret mint a fôhôsnô metaforáját használja; többértelmú azonban az a cselekedet, amikor Bussy ebbe a térbe behatol.

Az ilyen színrevitelek szimbolikus szerkezete, melyben a színpadi tér egy karakter fizikai vagy pszichológiai beállítottságát tükrözi, semmiképpen sem jelentett innovációt a korabeli nézôknek; ahogyan a mai, színháztudománnyal foglalkozó szakemberek számára evidens ez a fajta szerkesztési elv, úgy a koramodern színház közönségének is jól ismert, könnyen értelmezhetô megoldás volt. Gyökerei a moralitásjátékokhoz nyúlnak vissza, melyekben allegóriaként, külsô cselekvések sorában kerül bemutatásra a keresztény ember küzdelme a világ hiúságaival szemben. Ezekben a drámákban a fôhôs minden egyes pszichológiai jellemzője más-más karakterben manifesztálódik (a klasszikus psychomachia szerkezetben, mely a lélek konfliktusait jelenítette meg), s a színpad a fôszereplô bensójének [self] térképeként funkcionál, gyakran az égtájak szimbolikus jelentésével indokolva egy-egy szereplố adott irányból való felbukkanását. A moralitásjátékokban a keresztény ember kétszeresen is megjelenítôdik: egyrészt az azt alakító színész, másrészt a jó és rossz harcának helyet adó tér által. Catherine Belsey szavaival élve a keresztény szereplô a kozmikus harc „pillanatnyi helyszíne”. ${ }^{[12]}$ A Macro kézirat utasításai például körként hivatkoznak a The Castle of Perseverance címú darab színterére; ez a kör azonban, mely elsôsorban a világ mikrokozmoszának helyszínéül szolgál, egyben a keresztény ember makrokozmoszaként is múködik. A játéktér az Emberiség vándorlásának színtere, ahol a különbözô kísértések a színpad szélén felállított állványokon helyezkednek el. A játéktérben azonban a kísértések, az Istent megtestesítô szereplóhöz hasonlóan oda tudnak lépni a fôszereplöhöz, behatolva abba a térbe, amely az Emberiséget, annak lelkét és tudatát jelenítette meg. 


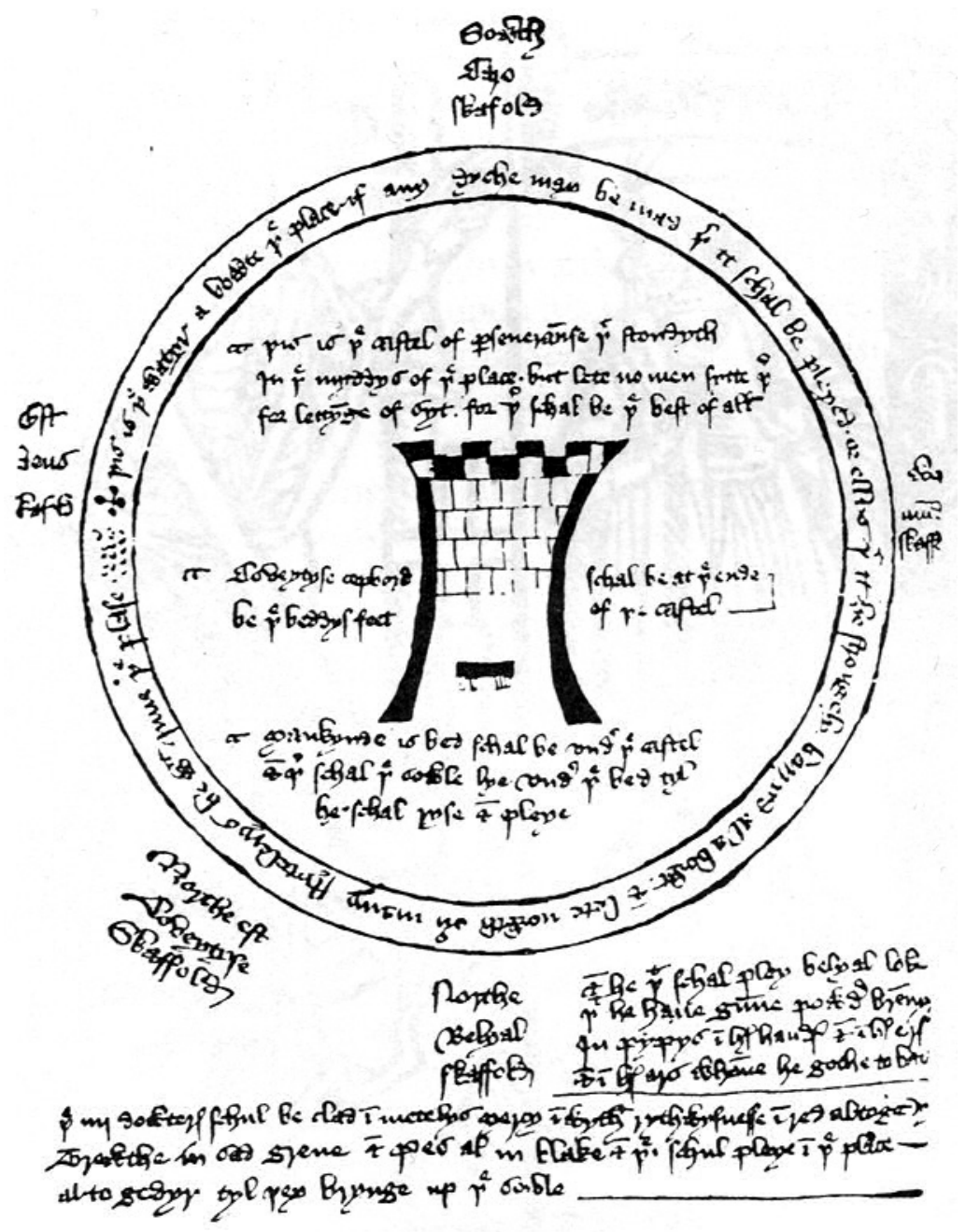

A játéktér rajza a Macro kéziratból, amely a teljes szövegú angol nyelvü drámák legkorábbi írott emléke. Forrás: wikimedia

Arra is akad példa, hogy a koramodern színház a színpadot (vagy legalábbis egy részét) a fôszereplô alakjának megtestesítésére, kifejezésére használja. Belsey rámutatott, hogy a feszültség bizonyos momentumaiban a koramodern darabok hajlamosak voltak a moralitások játékhagyományára támaszkodni, megteremtve ezzel „a realizmus és absztrakció kettôséből fakadó feszültséget”, vagyis azt a pillanatot, mikor a pszichológiai dráma már-már archetipikus mintát ölt magára. ${ }^{[13]}$ Ez a hagyomány gyakorta megjelenik olyan darabokban, melyek tematizálják a penetrációt, vagy több ízben ábrázolnak behatolással kapcsolatos cselekvést. Szándékosan használom a penetráció kifejezést - ez a szó etimológiailag a fallikus penile-hez kapcsolódik (utalva ezzel az aktus szexuális, ha nem erotikus értelmére), de a földrajzi peninsula [félsziget] terminushoz is közel áll, mely a latin penetrare szóból ered; jelentése körülbelül annyi, mint „belehelyez”, „behatol” vagy „áthatol”. Ezek az egymáshoz szorosan kötôdô kifejezések a penetráció térbeli (akár földrajzi) aspektusát hangsúlyozzák. Maga a „penetrál” szó egy olyan behatolást implikál, mely általában erôszakkal vagy erőfeszítések árán történik valaminek a belsejébe, valamint keresztül. ${ }^{[14]}$ A fogalom figuratív jelentése már Shakespeare idejében kialakult: „behatolni a fülbe, a szívbe, vagy valakinek az érzéseibe; mélyen hatni valamire; „megérinteni«.” 
Az angol nyelv viszonylag késôn integrálta a latin eredetú kifejezést, melyet szinte azonnal felesleges jövevényszónak kiáltottak ki. Puttenham azonban felszólalt védelmében: „Önök a következô szavakat kifogásolják még: penetrál, penetrálható, indignitás, de jómagam nem látom be, hogyan válhatnánk meg tôlük... nyelvünknek szüksége van ilyen értelmú szavak használatára." [15] A kifejezés jelentésárnyalatain keresztül szeretném bemutatni a penetráció különféle dramatikus és tematikus példáit, hogy felívjam a figyelmet arra az inherens szubjektivitásra, amely az ember megtestesüléssel kapcsolatos tudatosságára jellemzô.

Ezekben a dramatikus példákban a térbeli penetráció egy bizonyos karakter belső énjébe, tudatába való bejutás összetett ábrázolását szolgálja. A helyszín, mely a behatolást elszenvedi, lehet egy karakter személyes tere, a színészek egy csoportja által létrehozott tér, a színpad egészének a tere, vagy akár a közönség személyes tere. Az a vélt identitás [self], amelyet a felsorolt terek megjeleníthetnek, lehet egy pusztán anyagi természetú test; egy testrész (például vagina vagy pénisz), egy elme (vagy szubjektivitás) vagy szív (a konkrét szerv, vagy a vágyakozást és szerelmet jelölő konvencionális szimbólum). A különbözô identitás-értelmezéseket feltáró térbeli behatolások [intrusions] annak a komplexitásnak a mutatói, amely az identitással kapcsolatos koramodern tapasztalatot jellemzi. Ezeknek a lehetôségeknek a részlegességét akkor látjuk, ha olyan szemléletmódot tudunk kialakítani, amely jobban támaszkodik a megtestesülés gondolatára. $[16]$

Belsey meglátása szerint a szelf moralitásjátékokban ábrázolt modellje kizárja a beszélő szubjektum lehetôségét, hiszen még a föszereplố is híján van a cselekvőképességnek. Ezen kívül nem csak elveti a moralitásjátékot, mint a szubjektivitás lehetséges helyét, de oly módon tárja fel annak reneszánsz drámával való viszonyát, hogy megkérdôjelezi a régóta fennálló kritikai álláspontot, miszerint az irodalmi szubjektivitás az angol reneszánsz színpadon született meg. Belsey szubjektivitás-definíciója a liberális humanista modellben gyökeredzik; az általa elképzelt, nyelven és beszédképességen alapuló szubjektum egy „diszkurzív,... gondviseléstôl és nyelvtôl függetlenül létező", kizárólag intellektuális képességek által meghatározott hôs, akinek testisége tökéletesen figyelmen kívül marad. ${ }^{[17]}$ Azok a karteziánus modellek, amelyek meghatároznak egy ilyen modellt, egyben korlátozzák is, teljesen figyelmen kívül hagyva a habitus, vagyis a testtapasztalás jelentôségét. A testrôl szóló számtalan tanulmány ellenére a fizikai tapasztalat belsô múködése - amit Gail Kern Paster a „testben levés szubjektív megélésének” [subjective experience of being-in-the-body] nevez - háttérbe szorult a tapasztalat megjelenésének „objektív” vizsgálatával szemben. ${ }^{[18]}$ Mivel ez a hiányosság csak az utóbbi években ragadta meg a teoretikusok figyelmét, a dráma területén még nagyon kezdetleges szakaszban jár az alkalmazása.

A testiség (más szóval korporealitás) fizikai megtapasztalása létrehoz egy olyan típusú szubjektivitást, mely folyamatos interakcióban van az anyagi világgal - a környezettel, illetve az élő és élettelen tárgyakkal. A szubjektivitásnak ez az aspektusa kulcsfontosságú szereppel bír a vizsgálatom során, láthatóvá teszi az általam taglalt „penetrációt”, és a jelenségnek szélesebb körü jelentôséget biztosít, ezzel elôsegítve a „szelf” különbözô, szimultán múködô jelentéseinek felismerését. A tér teremtése címú múvében Henri Lefebvre marxista elméletíró a szelf fizikai 
aspektusának a szubjektumértelmezésünkbe való újraintegrálását kezdeményezte. Érvelése szerint Descartes elmélete a szelf és a test alapvetố elkülönítését vezette be, és rossz irányba terelte a szelfről való gondolkodást, ezzel megteremtve egy potenciális válság lehetôségét: „A karteziánus logika eljövetelével... a tér az abszolút birodalmába került”. ${ }^{[19]}$ Lefebvre magyarázata alapján a térre vonatkozó elképzelések teljesen absztrakttá váltak, mintha a szubjektivitást kihagyhatnánk az érzékelésünkból.

Egyes vélekedések szerint a tudományos megközelítés (vagyis az „episztemologikus” logika alkalmazása a már megszerzett tudásra) „strukturálisan” kapcsolódik a térbeliséghez [...]. A körkörös gondolkodás vádját tökéletesen figyelmen kívül hagyja, a diskurzus ellentétet tételez a tér és szubjektum státusa, illetve a gondolkodó „én” és a gondolkodás tárgya között. Az episztemologikus gondolkodás [...] megszüntette a „kollektív szubjektumot", vagyis az adott nyelvet létrehozó emberek csoportját, ahol a nyelv sajátos etimológiai szekvenciák hordozója [...]. A személytelen „az” vált a nyelv általános teremtôjévé, a rendszer teremtôjeként. Nem tüntette el ugyanakkor a szubjektum iránti vágyat. Így jelent meg újra az absztrakt szubjektum, a filozófusok által vallott cogito. [20]

Máshogy megfogalmazva, a tudományos megközelítés - descartes-i ideákból táplálkozó természete miatt - egy hatalmas szakadék kialakulásához járult hozzá, amely a tér nyugati kultúrára jellemzố számszerúsitése között és az egyének sajátos tértapasztalata között feszült. A francia tudós tanai azonban más területeken is éreztették hatásukat; a tudományos gondolkodáshoz hasonlóan így például a filozófia is elveszítette a szelf egy alapvetố komponensét, elfogadva a személytelen „azt”, mint egyéni szubjektumot, és mint a társadalmi szubjektum helyettesítójét. A újabb keletú meghatározások - mint például Yi-Fu Tuan vagy Edward T. Hall munkái a teret - ahogyan azt ismerjük és megtapasztaljuk - az érzékszerveink által alakított jelenségként definiálják: az érzékelésben a látványnak, a hangnak és az érintésnek egyaránt szerepe van. Ráadásul mivel minden egyén saját maga alakítja a térrôl való felfogását, annak érzékelése, hogy hol van, befolyásolja az egyén énérzékelését. Annak ellenére, hogy gyakran használják a „társadalmi hierarchia” és a „létezés nagy láncolata” metaforájaként, a tér valós, tapintható tapasztalat: lehet száraz vagy nedves, zsúfolt vagy kihalt, tágas vagy szúk, stb. Még ez a rövid, tapasztalati alternatívákat felsoroló lista is a - nyelv és akarat irányításától független fizikai érzékelés sokszínûségét mutatja. Az irodalomtudós Cynthia Marshall rávilágít, hogy a koramodern kultúrában „számos olyan jelet lát, amelyek a [tudatos, önmagát meghatározni képes individuumtól] való távolságot mutatják"; hozzá hasonlóan én is egy értelemtôl és akarattól önállóan múköodô énérzékelést állítok. ${ }^{[21]}$ A szubjektivitásnak ez az élménye a közvetlen fizikai tapasztaláshoz kapcsolódik, azon belül is a propriocepcióhoz, ami a helyzetérzést meghatározó ingerek, valamint a végtagok és más testrészek mozgásának érzetét értelmezi. Ahogy Paster is rámutat, „a testiség az öntudat [self-presence] legkezdetlegesebb formája.” ${ }^{[22]}$ Az ember létérzékelése elsôsorban a test fizikai megtapasztalásából ered.

A fizikai jelenlét megtapasztalását részben biológiai tényezôk határozzák meg. A 21. század 
társadalomtudósa, Edward T. Hall állatpszichológusok (mint például Hediger, C. R. Carpenter és A. D. Bain) emlősöket tanulmányozó munkájára építette fel kutatását, mely az emberek territoriális viselkedésének elemzését célozta. Hall részletesen vizsgálta, hogyan vesznek részt a tér érzékelésében a test különbözô részeiben lévô idegek a halló- és szaglószervi, illetve a hôérzettel kapcsolatos információk közvetítése által. Hollis Huston szerint Hall elmélete „nem viselkedésformákat ír le, hanem olyan állandó ingerküszöbök skáláját elemzi, melyekre az emberek (egyéni és csoportos szinten) különbözôképpen reagálhatnak”. ${ }^{[23]}$ A skála olyan fiziológiai tapasztalatokra vonatkozik, melyek kultúrákon és - az emlősök osztályán belüli fajokon átívelve is állandóak, a különbözó élólények és kultúrák azonban eltérôen reagálhatnak ezekre az ingerekre, benyomásokra. A hatalmi intézmények megpróbálhatnak befolyással bírni a térérzékeléssel kapcsolatos válaszreakciókra, megkülönböztetve a férfiakat a nôktôl, az arisztokratákat az alsóbb vagy középsô társadalmi osztályok képviselôitôl - így hozva létre egy szociális vagy nemi különbségek mentén meghatározott kultúrát. Ilyen esetben az érintettek a fiziológiai ingerek pszichológiai válaszait meghatározó doxa strukturálásában vesznek részt. Ezáltal a hit összekapcsolódik a tettel, sốt az érzékeléssel is, bár ami igaz a doxára - amely Bourdieu szerint mint beépített alapelv „kívül esik a tudatosodás folyamatán, tehát mentes a tudatos és szándékos változtatástól, sôt a magyarázattól is: úgy túnik, semmi sem kifejezhetetlenebb szavakkal" -, az méginkább igaz a testiség megtapasztalására. ${ }^{[24]}$ Számos koramodern, nôi viselkedésnormákat leíró könyvben megnyilvánul annak az igénye, hogy egy adott társadalmi csoportot ilyesfajta szabályokkal regulázzanak: az úri hölgyek ugyanis nem tarthatták sajátjuknak testüket, csupán számos társadalmi megkötéssel való szabályzás után, amelyeknek feladata egy, a továbbiakban internalizált habitus kialakítása volt. Idôben sem volt ritka a különbözố csoportokra irányuló szabályok bevezetése; az úri hölgyek teste például társadalmi tulajdonnak minôsült, feladata pedig az volt, hogy más nôk számára példakövetô, elsajátítandó habitust mutasson. A lesütött szemú, gyámoltalan fellépés például kiváltképp elvárt magatartásnak minôsült, a pirulás pedig a tiszteletteljes viselkedés és a szúziesség jelének számított. ${ }^{[25]} \mathrm{A}$ hölgyeknek ezen kívül türelemmel kellett viselniük a fizikai közelséget, melybe - társadalmi pozícióiktól függetlenül - a büntetô testi fenyítés is beletartozott. ${ }^{[26]}$ A nôket arra tanították, hogy fizikailag ne szálljanak szembe az agresszív csábítással vagy akár a szexuális kényszerrel. ${ }^{[27]}$

Ez a tökéletesen foucault-i fegyelmezés bizonyára el is érte azt a célt, hogy egyfajta önmegtagadással tekintsenek magukra a nôk, akik megfeleltek a nemük és társadalmi rangjuk alapján elvárt viselkedési normáknak. A fizikai tapasztalás egyik aspektusa a minket körülvevố tér, vagyis a „személyes tér” uralása; Edward Hall ezzel kapcsolatban alkotta meg a proxemika kifejezést, mely az egyén téralkotásának és -érzékelésének tanulmányozását helyezi fókuszba. Hall vizsgálata szerint a tér kiterjedésének észlelését termikus, valamint ennél konkrétabban taktilis és vizuális információk határozzák meg; a tudós - többek között - a következốt állapította meg: „Az ember térigényét egészen a legutóbbi idôkig általában a konkrét testtérfogatával azonosították. Nem törődtek vele, hogy az ember - személyiségének extenziójaként - igényli az elóbbiekben ismertetett zónákat is.” [28] 
A John Ford Kár, hogy kurva címú tragédiájában ábrázolt nôi habitus, vagy a testben való létnek az élménye jelentôs zavarodottságról tanúskodik a nôi éntudat természetét illetôen. A férfi fốszereplôk olyan gyakran utalnak klisészerú kifejezésekkel Annabellára, hogy a hôsnôt majdhogynem puszta kellékké redukálják: a nô egy edény, az erotikus vágy tárgya, amelybe a férfi szereplők be kívánnak jutni. [2-5. Kép: A Kár, hogy kurva néhány jelenete a Magyar Színház 2010es elôadásából, Koltai M. Gábor rendezésében. Forrás: Vereckei Rita díszlettervezố honlapja. http://nezoke.blogspot.hu/2010/12/kar-hogy-kurva.html] A koramodern drámában gyakran használtak mimézisen alapuló metaforákat az erotikus jelenetek színrevitele során; ilyen volt például a színpadra való belépés, mely - különösen, ha fizikai és/vagy agresszív módon történt - a szexuális penetráció allúziójaként szolgált. A behatolás azonban - helyszíntôl függôen - egy karakter szubjektivitásába (elméjébe, szivébe vagy lelkébe) is történhetett. Habár Annabella teste több karakter figyelmének is a középpontjában áll, magát a szerzôt is aggasztja a nô teste és „bensôje” közötti viszony; ez az aggodalom konkrétan manifesztálódik a színpadon is, ahogy a szöveg által megjelenített képek a figyelmünket a metafora, a színrevitel és cselekmény viszonyára irányítják.
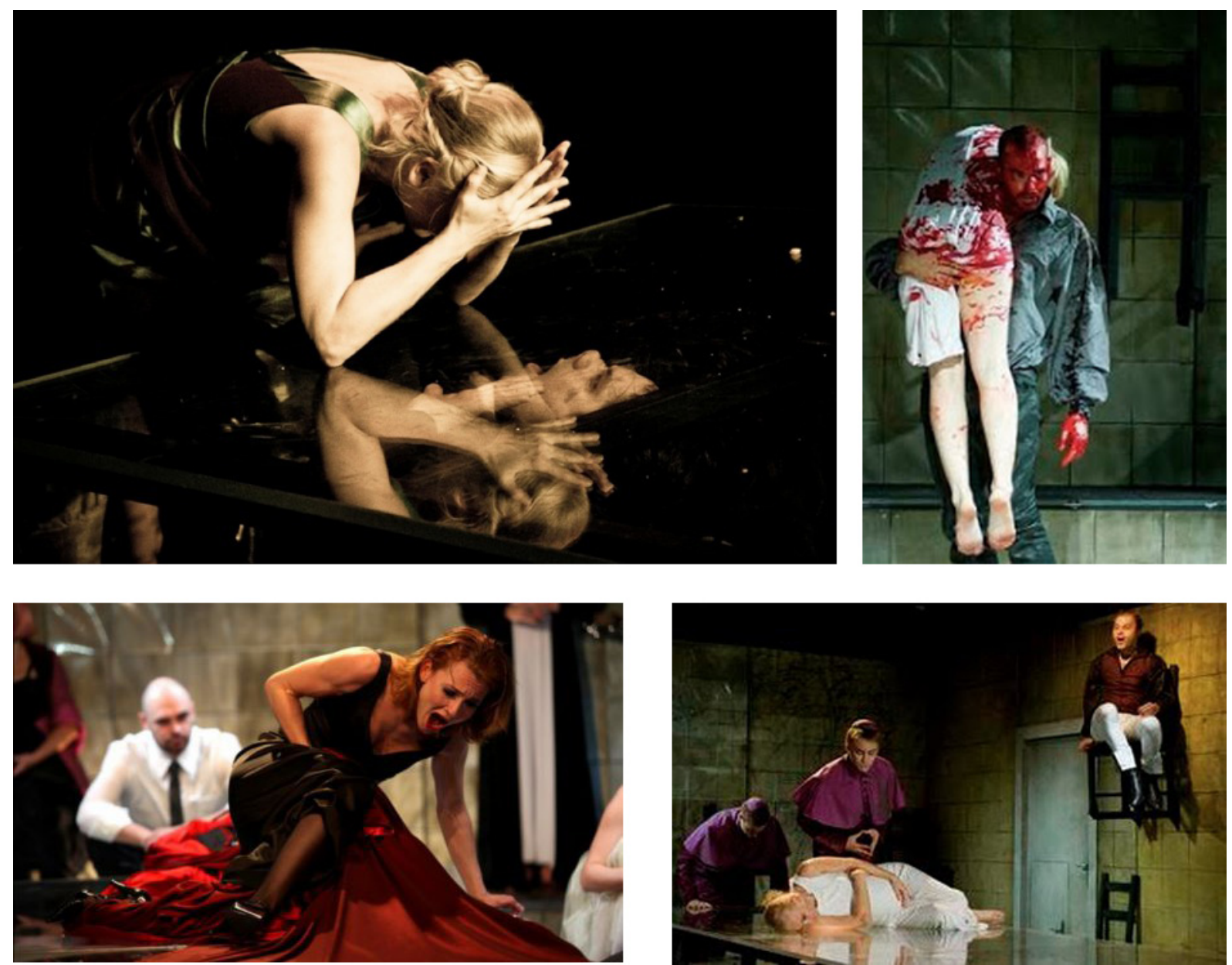

A Kár, hogy kurva néhány jelenete a Magyar Szinház 2010-es elôadásából, Koltai M. Gábor rendezésében. Forrás: Vereckei Rita díszlettervezö honlapja. 
A darab metaforái többször utalnak különbözô tárolóeszközökre, és ezek közül számos éppen Annabella testét jelöli meg tartályként. ${ }^{[29]}$ Ám a bekebelezés egyéb metaforái a testet általánosabb értelemben metaforizálják, olyan formában fejezik ki a szubjektivitást, amely a korban jellemzô volt. A testvérek pásztorórája után Annabella így szól Giovannihoz: „Csak menj, amerre akarsz, én lélekben itt tartalak” (2.1.39). ${ }^{[30]}$ Shakespeare és Sidney szonettjeiben is gyakran visszatérô motívum, hogy a szerelmes kedvese alakját lelkében [mind] vagy lelkének szemében [mind’s eye] ôrzi (ezt ma leginkább a szubjektivitás jeleként értelmezik). Ford, a szerzó meglepő hasonlósággal visszhangozza Antonius nyitószövegét az Antonius és Cleopatra címú Shakespeare drámából (valamint kortársa, John Donne verssorát) Giovanni egyik megszólalásában: „Könyvmolyok álmodjanak más világot, / Az én világom s boldogságom itt van" (5.3.13-14) - erre az Annabellára vonatkozó utalásra pedig aligha lehetne mondani, hogy pusztán szexuális jelentéssel bír.

Más szereplôk Annabellával kapcsolatos megnyilatkozásai is hasonló képeket közvetítenek; a Páter például a következő megjegyzést fúzi a lánynak adott tanácsa mellé: „De várjunk: / A megbánás új múvét látni vélem szívedben" (3.6.31-32). Annabella szíve a nô belsố állapotát tükrözi, az atya látomása pedig a külsô megjelenésen túli látás képességét. A nô belsôjére irányuló utalások megismétlődnek, mikor Soranzo rájön, hogy újdonsült felesége állapotos. A megcsalt férj elfojtja haragját, és különbséget tesz önmaga és Annabella szeretôje között: „Hidd el, hogy bárki volt az a bitang / Szégyenbe csábító, tán megkívánt / De sosem szeretett úgy, ahogy én. / A képen csüngött, mely orcáidon / Díszlett, és tetszett szeszélyes szemének, / De szívedet szerettem én, s amint / Hittem, erényeidet” (4.3.125-29). Mind Soranzo, mind a Páter nem szexuális jellegú penetrációt szeretnének végrehajtani: a nô szíve rejtelmeinek feltárását. Általuk Annabella tudata és szubjektivitása is legalább annyira hangsúlyossá válik a darab folyamán, mint teste.

A külső és belsô bizonytalan viszonya fölött érzett aggodalom a színpadképben és a színpadi cselekményekre való verbális utalásokban is megjelenik. Egy olyan darab nézése során, melyben a nyitóbeszéd a testi tér fontosságát hangsúlyozza, és elítéli az magánterületre való erôszakos behatolást, a nézô arra számíthat, hogy behatolások sorozata fog megelevenedni a szeme elôtt. Még Annabella egyik szobalánya is megfogalmazza ezt az elvárást: „No, gyermek, hogy tetszik ez magának? Itt aztán / fenyegetôznek, kihívják egymást, és vívnak mindenfelól / s mindezt magáért. Vigyáznia kell magára, / kincsem, különben ellopják, mikor alszik" (1.2.63-66). Ennek ellenére kevés olyan jelenet található, melyben az udvarlók agresszívan törnének a nô magányára. [31] Giovanni és Annabella apjuk csarnokában jönnek rá kölcsönös vonzalmukra; ez a mindkettejük számára semleges terület lehetôvé teszi, hogy egymás személyes terének megsértése nélkül találkozzanak. (Akár az endogámia extrém formájának is értelmezhetjük Annabella hajlandóságát arra, hogy erotikus választása testvérére essen, hiszen így még a családi kört sem kell elhagynia). Miután örök húséget fogadnak egymásnak, Annabella és Giovanni távoznak a színrôl, feltehetôleg azért, hogy elhálják a nászt. A következô jelenet azonban nem e beteljesülését, hanem Bergetto Annabella iránti, bohózatba ágyazott közönyét ábrázolja. Ezután lép csak be a pár, „mintegy a 
szobájukból"; megújítják esküjüket és ígéretet tesznek, hogy húek maradnak egymáshoz. Ez a cselekménykezelés megfosztja a közönséget a nôi test bemutatásától; helyette csak Giovanni udvarlásának parodisztikus kifordítását követheti nyomon. A színrevitel így a közönséget saját buja vágyával szembesíti, hogy leplezetlenül láthassa azt az erotikus jelenetet, amelyet a darab kezdetben ígérni látszott. Ahogy Patricia Fumerton rámutatott, ebben az idôben a szubjektum,

bár ideje nagy részét nyilvános helyeken töltötte, fenntartott magának egy titkos szobát, szekrényt, dobozkát vagy más kis elzárt rekeszt a ház egyik eldugott zugában... A privát térbe való visszahúzódás természetes részét képezte az arisztokratikus, fônemesi énnek. Ez a fajta tartózkodás azonban a legtriviálisabb ügyek kapcsán is olyan gyakran megnyilvánult, hogy megakadályozta a privát szféra tulajdonképpeni létrejöttét. [32]

Úgy túnik, ez a titkos szoba már sosem lesz felfedve. Annabella még Putana elôtt is mereven elutasítja, hogy részleteket szivárogtasson ki az együttlétrôl.

Sürgetô vágyuk ellenére Annabella udvarlóinak nem igen adatik meg, hogy közel kerülhessenek kiválasztottjukhoz. A Grimaldi által elért szinte egyetlen érintkezés akkor következik be, amikor Annabella és Putana „fent” érkeznek a színpadra Grimaldi és Vasquez csatája után. A szöveg színpadi utasítása minden bizonnyal arra utal, hogy a két nố a harcot felülrôl figyeli, egy ablakból vagy balkonról, ahonnan az utcára látnak. Annabella végig az erôszak „fölött” marad, attól elhatárolódik, és közvetlenül sosincs veszélyben. Bergettóval közös randevúja is csak elmesélés szintjén jelenik meg, nincs színre víve. Igaz ugyan, hogy késôbb a lány - apja utasításának eleget téve - elolvassa hódolójának levelét, de ezután engedélyt kap rá, hogy elutasítsa a férfi további próbálkozásait. Soranzo udvarlása közben a páros besétál az apa csarnokába; e biztonságérzetnek köszönhetôen Annabella még élcelődik is. Még akkor is sikerül megôriznie a nyugalmát, mikor férje rájön titkos viszonyára. A színpadi utasítások így írják le belépésüket: „Belép Soranzo, félig felöltözve, és magával ráncigálja Annabellát” (4.3.1 s.d.). Arra következtethetünk, hogy a közös hálókamrából jönnek, ahol egymás levetkőztetése után fény derült Annabella állapotára. Ford nem ábrázolta a hálószoba-jelenetet, s ez a tény is csak Soranzo bukását hangsúlyozza: nem sikerült áttörnie Annabella védelmét, a penetráció kudarcba fulladt. A nô nem hajlandó elárulni szeretôje nevét, helyette egy dalt dúdolgat, melyben halál iránti közönyét fejezi ki. Soranzo így még házasságuk ellenére sem nyer hozzáférést Annabella belsô énjéhez.

Annabella hálószobája csak késôbb jelenítôdik meg a színen, mikor a nô hangot ad megbánásának. A színpadi utasítás a következőket mondja: „A páter egy székben ül, Annabella előtte térdel és suttogva beszél neki, elôttük egy asztal, rajta viaszgyertyák, Annabella sírva tördeli a kezét” (3.6.1.s.d.). ${ }^{[33]} \mathrm{A}$ jelenet in medias res kezdődik a páter megszólalásával: „... oly romlott, búnteli lelket / Tártál fel, be kell vallanom, csodálom / A földet, hogy megtưrt hátán...”. Kétségtelenül ô uralja a jelenetet beszédével, amit csak alkalmanként törnek meg Annabella felkiáltásai. Miután a pap élénken lefesti, milyen gyötrelmek várnak Annabellára a pokolban, a nő felteszi a kérdést: „Nincs, ami megválthatna nyomoromban?”(3.6.33). ${ }^{[34]}$ A férfi válasza meggyôzi arról, hogy a Soranzóval való házasság a megfelelố út, s mikor megkérdezi Annabellától, hogy beleegyezik-e, a nô azt 
válaszolja: „Bele” (3.6.42). [35]

Habár a színpadi utasítások azt sugallják, hogy a nô és a Páter együtt jelennek meg a színen, Annabella testtartása és a jelenet közben elhangzó beszédek arra utalnak, hogy Annabella rejtett szubjektivitása végre felszínre került. A jelenet megmutatja, amire oly régóta vártunk: Annabella hálókamráját. A feminin térbe valóban behatol egy agresszív férfi - a Páter, akinek kényszerítô szavai mintegy támadásként érik a nô személyes terét. Ebben a szentélyben azonban nem Annabella testét, hanem lelkét látjuk kitárulni. Annabella énjének régóta várt feltárulkozása nem egy akaratos, hanem egy bölcs nốt bocsájt a nézók szeme elé. A Páter egy tisztán lelki térhez fér hozzá.

Annabella karakterének ilyen irányú értelmezését azonban megtöri a darab végkifejlete. Az ötödik felvonás utolsó elôtti színében Ford bepillantást enged a szerelmi fészek baldachinja mögé, ahol Giovanni és Annabella ismét ágyban látható. ${ }^{[36]}$ A férfinak nincs szüksége agresszív fellépésre, hiszen már korábban magáévá tette Annabella testét. A jelenetben Annabella belsô tere erotikus töltetet kap, és a pár a maradék idôben újrajátssza az eredeti együttlétet, amelyben Annabella testét meghódítja egy férfi. Miközben leszúrja Annabellát, Giovanni egy erôszakos, és egyben szexuális penetrációt hajt végre, elpusztítva az áruló magzatot, mely szerelmét Soranzóhoz lökte („boldogtalan gyümölcs méhében tôlem kapott / Életet, bölcsốt, sírt” [5.5.94-95]). Annabella bensője kifordul, miközben a színrevitel közszemlére teszi testét, melyet - a szöveg szerint Giovanni fontosabbnak tart húga lelkénél. A színpadi tér újra csak a nô bensôjét reprezentálja, ám ezt a bensốt nem Annabella szíve hivatott képviselni, hanem a nemi szerve.

A darab végén újra megjelenik a szív motívuma. Miután azonban immár egy tényleges szerv jelölőjévé válik, a bensô végül megismerhetetlen marad. Ami bensô, ahogy Katharine Maus fogalmaz, „nem vizsgálható, rejtve marad mások szeme elôtt. Felülmúlja a láthatót - érvényessége vitathatatlan”. ${ }^{[37]}$ Miután Giovanni belép a színpadra „tôrén egy szívvel”, a látvány kétségtelenül azt a korai jelenetet idézi, melyben a férfi arra kéri szerelmét, hasítsa szét mellkasát, mert szivére „van írva a kimondott igazság” (5.5.7 s.d). A szív mint az örök szerelem helyének trópusa - amely annyira gyakori Shakespeare, Sidney és Donne múveiben - itt szó szerintivé válik, ahogy Giovanni saját gyốzelme jeleként hordozza végig a teremben.

Tettem fénye e napot

Megvakította, délből éjszakává.

De lakmározni jöttem én is, dúsabb

Lelőhelyen, mintsem ékkő, arany 
Felérhetné; egy szív ez, uraim,

Egy szív, mely az én szívem sírja lett:

Nézzék meg jól, ráismernek talán?

$(5.6 .22-29)$

A férfi beszéde egy trágár szójátékot sejtet, melyben a „dúsabb lelóhely” valójában Annabella nemi szervének metaforája. Ford azonban megvezeti közönségét, és ismét megváltoztatja a tárolóeszköz jelentését: Giovanni húga érzéseinek - nem pedig testének - megnyerésével büszkélkedik. A tartály, a „dúsabb lelóhely” nem a vaginára utal, hanem a szívre, mely - Giovanni reményei szerint Annabella iránta táplált érzelmének tiszta, egyértelmú jele. Ez azonban természetesen nem így van. Még Giovanni apja sem ismeri fel Annabella szívét (Giovanni bizonygatja: „Miért riadoznak? Esküszöm, övé”). A színpadon megjelenítve a szív nem több, csak egy véres húsdarab: híján van mindenféle azonosításra alkalmas jelnek, arról a szimbolikus tartalomról nem is beszélve, amely Giovanni számára olyan értékes. [38]

Színházi értelemben, ahol a cselekmény és a színpadkép egyaránt kifejezésre jut, Annabella belsôje - nehézkesen ugyan, de - végül felszínre kerül, ráadásul nem is egyszer. Szobájának és ágyának színpadon való megjelenítése által nem csak láthatóvá válik a nô bensôje, de a színpadkép szerves részévé is vált. Ahogy Georgiana Ziergler a Lukrécia elrablásáról szóló tanulmányában fogalmaz „a hálókamra a nô identitásának [self] és testének metaforájaként múködik”. [39] Ebben a múben azonban a „szelf” többféleképpen is megjelenítődik: lehet a lélek, a lelkiismeret, a nemi szerv és a méh is. De hol lakozik a képzelet, a szívben, a fejben vagy a vaginában? A kérdést Ford nem tudja eldönteni, ezért a szelf központját folyamatosan váltogatja: Annabella belsô világa egy mozgó célpont, karaktere pedig sehol sem annyira ellentmondásos, mint a darab végén.

A Kár, hogy kurva a moralitásjátékok konvencióihoz igazodik: színre viszi az arisztokratikus nôi testet, hogy aztán megvizsgálja annak szubjektivitását. A szereplők és közönség közötti pszichológiai távolság is a moralitások hagyományait tükrözi. Szenzációhajhász természete ellenére - vagy éppen amiatt -, a darab leginkább intellektuális játékként funkcionál, melyben a közönségnek fel kell derítenie Annabella szubjektivitását. A Macbeth-től eltérôen Ford múve nem enged bepillantást nyerni a fôszereplő belsô világába, sokkal inkább intô lecke marad, a moralitásokhoz hasonlóan.

A darab nézőjeként egyetlen lehetséges szerepben tetszeleghetünk: a bámészkodó, kukkoló szerepében. A voyeurisztikus vágyak létjogosultságot nyernek azáltal, hogy a nézô fizet. Annabellának melyik részét akarjuk tehát látni? Giovanni szenvedélye vágykeltóként hathat ránk, sóvárgásának vérfertôzố természete azonban viszolyogtató. A darabot az Artaud-féle Könyörtelen Szinházzal hozzák kapcsolatba a véres jelenetek és a témája, de leginkább a Kár, hogy kurva által felkínált nézôi pozíció kapcsán. Giovannival látjuk az eseményeket, vagy a válla fölött leskelődünk? És ezek közül melyik szerepben hasonlítunk rá jobban? A nézôi szerepben rejló 
ambivalencia - saját vonzódásunk egyszerre csábító és taszító volta - azonban általánosabb kérdéseket is feszeget, mégpedig a színészek és közönség között létrejövô tranzakciókkal kapcsolatban. Mi az, ami bevon bennünket a cselekménybe? És hogyan módosul a szereplókhöz kötődô viszonyunk, ha bevonódunk? Minden karakterrel együtt tudunk érezni, egymás után, vagy csak eggyel, tehát kettôs nézôpontot élvezünk-e, miközben a „saját” szereplônk nézôpontján keresztül figyeljük a többit? Nem számít, mi a cselekmény; amint egy szereplố kapcsolatot teremt egy másikkal, térbeli viszonyuk megváltozik, és átrendezôdik mindkettônek a közönséghez való viszonya is. Hollis Huston így írja le ezt a jelenséget:

Hall átfogó viselkedéstanulmányának közvetlen színpadra adaptálása végzetes hiba [lenne]. A színpadot a való élettôl az alapvetôen proxemikus jelleg különbözteti meg ... A színházban az alapvetố kapcsolat nem két színész, hanem a színészek és a közönség között jön létre: ha a kölcsönös felelôsség megszúnik, a színpad meghal és a színház érvénytelenné válik. ${ }^{[40]}$

A nézôkre gyakorolt hatás elemzése kulcsfontosságú jelentőséggel bír a színrevitel elemzése során. Következésképpen a testrôl és a test színházban való használatáról szóló fejtegetésekbe szükséges bevenni a nézôt mint harmadik elemet, amellyel létrejön egy kölcsönös egymásrautaltságon alapuló, három pólusú kapcsolat.

Akkoriban sok színházellenes pamfletíró követelte a drámák betiltását; úgy gondolták, a színmúvek rossz hatással vannak a nézôkre, akik a darab nézése során kontrollvesztetté válnak. Stephen Gosson például többször is hangot adott a „bámulással” kapcsolatos aggodalmának. A Szinmüvek cáfolata öt felvonásban [Playes Confuted in Five Actions] címú alkotásában négy alkalommal is hangsúlyozza a látvány - pontosabban a látvány bámulásának - közönségre gyakorolt hatását:

Ha vagyunk annyira elóvigyázatosak, hogy semmilyen bálvány szennyét le ne nyeljük, milyen szorgalom, körültekintés és óvatosság kell ahhoz, hogy szemünket és fülünket is védjük a lélekrontó bálványoktól? ... hiszen amit látva s hallva veszünk magunkhoz, szellemünket fekszi meg. ${ }^{[41]}$

Phillip Stubbes is hasonló véleményen van a színházi tapasztalást illetôen: „Mert ilyen a mi buja és tompa természetünk: mélyebben hatol szívünkbe és elménkbe az, amit a szemünk elôtt látunk, mint az, amit csupán hallunk". ${ }^{[42]}$ Mindkét szerzố a látást jelöli meg a test kinyílásának eszközeként, mintha szemünk a szájhoz hasonlóan bekebelezné a vizuális ingereket; látásunk a testünkbe való belépésre csábítja az ingereket, arra, hogy „döfődjenek”, hatoljanak be. Hogy értelmezni tudjuk azt a támadást, amelyet a színházellenes szerzók szerint a színdarabok nézése intéz az identitás [szelf] ellen, elôször meg kell vizsgálnunk a koramodern színházlátogató esetében azokat a viszonyokat amelyeket Hall a távolságérzô szervek két fajtája, a „távolságérzékelôk” és a „közvetlen érzékelók” között feltételez. Az előbbi csoportba azok az érzékelốk tartoznak, melyek távolabbi objektumokat, tárgyakat képesek megvizsgálni, ilyenek pl. a 
szem, a fül és az orr. Az utóbbi csoport tagjai a testközelben levô tárgyak tanulmányozására specializálódtak; ide sorolhatóak a tapintással kapcsolatos érzékelôk, melyek a bőrünk, a hártyáink és izmaink által felvett ingereket dekódolják. ${ }^{[43]}$

Vajon hogyan érzékelte a darabot fiziológiai és zsigeri értelemben a koramodern színház közönsége? Az érzékszervek által? A Fortune Színház megépítéséről szóló szerződést alapul véve Bruce Smith a következőket állítja: „a Fortune-ban vagy az 1599-es Globe színházban senki sem volt 15 méternél távolabb a színpad elôterében s egyben a tér középpontjában elhelyezkedô színésztől". ${ }^{[44]}$ Ugyan a hallás szempontjából ez a távolság viszonylag kicsinek számíthatott, mégis távolinak érződött a térben, s a Hall által „nyilvános távolságnak” nevezett kategóriába esett - abba a típusba, ahol az emberek elveszítik az egymáshoz kötôdésük érzését. ${ }^{[45]}$ Hall kutatása szerint azoknak a színészeknek, akik arra törekednek, hogy játékukkal megérintsék a nézóket, el kell fogadniuk azokat a korlátokat, amelyeket ez a távolság kijelöl.

A legtöbb színész tudja, hogy 9-10 m-ről vagy még messzebbrôl elvesznek a normális hangerô közvetítette finomabb jelentésárnyalatok, csakúgy, mint a mimika és a mozgás részletei. Nemcsak a hangot, de minden más kifejezőeszközt is erôsíteni, nyomatékosabbá kell tenni. A kommunikáció nem verbális részének közvetítése szinte teljes egészében a gesztusokra és a testhelyzetekre hárul. Ráadásul a beszédtempó is lassul, a szavakat gondosabban kell kiejteni. ${ }^{[46]}$

A színpad elôtti térben lévố nézôknek ${ }^{[47]}$ - akiknek eleve közvetlen a színpaddal való kapcsolata erôsíti a közelség élményét, ha a színész a plateára (a színpad elülsô részébe) jön, mivel a színész társasági távolságba került [social distance]. Hall ennek a fizikai tapasztalatát enyhén kényelmetlennek írja le, hiszen aktív figyelést igényel, hogy felismerjük, mi van a közelünkben. A társasági távolság közeli szakaszában a

legélesebb látást biztosító mezô már magába foglalja az orrot és mindkét szem bizonyos részeit, vagy a teljes szájat, egy szemet és az orrot. Sok amerikai beszélgetôpartnere két szemén, vagy a szemén és a száján járatja tekintetét ilyen távolságból. [...] 120 cm-rôl $60^{\circ}$ os látószög alatt társunk fejét, vállait és felsôtestét láthatjuk. ${ }^{[48]}$

Még ennél is fontosabb, hogy Hall rámutat: „Fensôbbséges hatást vált ki, ha ilyen távolságból állva beszélünk ülô partnerünkkel”. ${ }^{[49]}$ Ebből (és a személyes tapasztalatainkból) nem nehéz arra következtetni, hogy a nyakunk begörcsölésével járó felfelé bámulás kiszolgáltatottá teszi az embert a benyomásaival szemben.

A nyilvános színházakban a kötényszínpad szinte az állóközönség közé furakodott. Egy olyan pódium, amely 12 méter hosszan nyúlt be a nézótérre, minden bizonnyal behatolt azoknak a személyes terébe, akik túl közel kerültek. A közelség izgalma ellenére a színpadhoz túl szorosan állók kényelmetlenül érezhették magukat, hiszen testük a keményfa építményhez nyomódott így talán még rosszabbul jártak, mint azok, akik a tömeg szélén az amfiteátrum falához 
préselôdtek. A színészeket három oldalról vette körbe a közönség; így a színész számára lehetetlen volt ugyanolyan vizuális élményt nyújtani, mint ha csak egy oldalra játszana. A kötényszínpadon ugyanakkor sokkal hatásosabb belépóket tudtak produkálni a színészek, különösen, ha - a meghittebb légkör elérése érdekében - a színpad hátsó részéből (locus) a színpad elôterébe (platea) jöttek. Ebben a kontextusban különösen kifejezô a fogalompár. Robert Weimann szerint a platea a „darab világa szimbolikus jelentésének részévé válik, míg a locus az önkifejezés és ábrázolás dialektikáját segíti.” Az egyikből a másikba való elmozdulás során a színészek „az illúzió és konvenció, ábrázolás és önkifejezés, komolyság és bohózat között közvetítettek - fizikai, társadalmi és színházi értelemben is kihasználva ezek dialektikáját." Weimann továbbá úgy véli, hogy a koramodern színész „olyan bevett mozdulatokat és szófordulatokat használt, melyek a locus és a platea konvencióit követték, ezáltal a közönség világa a játék részévé vált, a játék pedig bekerült a közönség világába.” [50]

Hogyan tudtak bizonyos forgatókönyvek és rendezések úgy hatni a közönségre, hogy azok a Gosson és Stubbes által leírt módon még jobban megnyíljanak? A színházi élmény segítségével be lehetett-e hatolni a közönségbe? A válasz valószínúleg nem, ha a 19. századi, proszcéniummal ellátott színház ültetett nézôire gondolunk, akik a színészeket egy zsúfolt, viktoriánus színpadképben, dobozszerú pódiumon láthatták játszani. A koramodern színházban azonban a közönség tömege által körbevett kötényszínpad feltehetôen lehetôséget adott erre, hiszen egy teljesen üres színpad várta az elôadó belépését, aki majd a teret értelmezhetôvé formálja.

Természetesen nem minden színházi belépés jelent agresszív penetrációt (pl. ahol a szereplók egy beszélgetés közben érkeznek meg a színpadra); egy magányos színész azonban elérheti ezt a hatást, különösen, ha megjelenését már elôkészítették korábbi erôszakos behatolás képei, az errôl való beszéd, ehhez kapcsolódó színpadkép vagy korábbi színpadra érkezések módja. ${ }^{[51]}$ A locusból plateába való elmozdulással a színész nem csak az üres színpad terébe hatol be, hanem abba a térbe, illetve afölé is, melyet a közönség saját tereként érzékel. Gurr is hasonlóan vélekedik errôl a jelenségrôl: „A színrevitel és a közönséggel való interakció fô jellemzője a meghitt, személyes viszony volt. A nézốk ugyanannyira látszódtak, mint az előadók, erejük pedig abban méginkább megnyilvánult, hogy teljesen közrefogták a színpadon lévô színészeket.” [52]

Színházi karrierje során Shakespeare többször is használt olyan figurákat a színpadon, akik a közönséget jelenítették meg, s így lehetôsége volt arra, hogy a színházában rendelkezésére álló fizikai körülményeken belül alakítani tudja a nézók térrel kapcsolatos tapasztalatát. Vajon miképpen vehette rá a közönséget a színpadi (intradramatikus) nézô térbeli tapasztalatával való azonosulásra az a kapcsolat, amely a színpadra való belépést olyan témákhoz társította, mint a testbe való behatolás vagy a test inváziója?

A Shakespeare Coriolanus címú drámájában megjelenő csôcselék nem egyszerúen az intradramatikus nézôt helyettesíti, mivel újra és újra a tömeg és az egyén, a rész és az egész, a zárt és a nyílt test közötti kapcsolatot tematizálja. A behatolás és a penetráció a darabot végig meghatározó témák, Shakespeare ugyanis folyamatosan a nyíltság, a sebezhetôség, az autonómia 
és az együttérzés szükségességére irányítja figyelmünket. A Coriolanus fôhôse Corioli városba való behatolása és annak megnyitása után kapja nevét, ố maga ugyanakkor nem veti alá magát a figuratív behatolásnak. Ellenáll a monologizálással járó sebezhetôség színpadi hagyományának, ami önmagában a behatolásra való nyitottság metaforája ${ }^{[53]}$; megtagadja sebei felmutatását a közönségnek, megakadályozza, hogy a közönség tekintete a vizuális és szimbolikus penetrációvá váljon. Nem veszi figyelembe sem a metaforikus gyomor igényeit (a római lakosság vágyait), sem a valódi szerv szükségleteit (az ételt mint a test szükségletét), ezzel elutasítva annak elismerését, hogy a testet külső és belsô ingerek egyaránt befolyásolják. ${ }^{\left[{ }^{54]}\right.} \mathrm{A}$ gyengeség legnyilvánvalóbb visszautasítása az az emlékezetes jelenet, amelyben Martius egymaga hatol be Corioli városába.

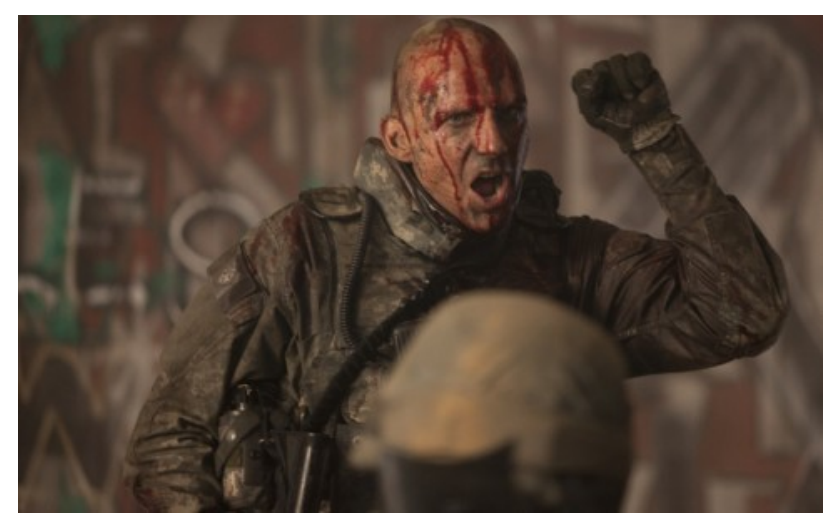

Ralph Fiennes az általa rendezett, 2011-es Coriolanus filmadaptáció cimszerepében

A színpadra való be- és kilépések a Coriolanusban felvetett témák révén szinte azonnal szimbolikus jelentôséget kapnak. A darab egy mozgalmas jelenettel nyit, melyet a zendülés morajai csak még hangsúlyosabbá tesznek: „Jön egy csapat zavargó polgár botokkal, fütykösökkel s egyéb fegyverekkel". ${ }^{[55]} \mathrm{Ez}$, mint ahogy a darab Arden sorozatban megjelent változatának szerkesztôje, Philip Brockbank megjegyzi: „a kor drámái közül az egyetlen, amely nyilvános erôszakkal nyit.” [56] A kritikus Jarret Walker is rámutat: ezt a fajta kezdést a nézók úgy érzékelik, mintha „frontális támadás érné a testüket." ${ }^{[57]}$ Az üres színpadot gyorsan elöntố zavargó, dühös és ellenséges tömeg csak egy volt a Király Emberei ${ }^{[58]}$ által használt bevett fogások közül; ez a megoldás kifejezetten azt a célt szolgálta, hogy az erôszak a támadás érzését keltse a közönségben. A nézôtéren ülôk teljesen másképpen élhették meg a dübörgéstôl hangos tömeg élményét, mint azok a bámészkodók, akik a színpad körül tömegeltek. [59]

Zvi Jagendorf úgy véli, Shakespeare szándékosan ütközteti az „egyedül álló ember elszigetelt, önmagában álló testét” ${ }^{[60]}$ a sokaság által alkotott testtel.

„Mindkettô a darab látványának szerves részét képezi. A tömeg - mely az utcán és a piactéren lévő polgárokból, illetve a csatatéren lévô katonákból áll össze - a cselekmény állandó eleme.

Kiabálásaikat a színpadon és azon kívül is hallani lehet; ez arra ösztönöz minket, hogy elképzeljük a gyôzelmi felvonuláson tolakodó emberáradatot, a tömegjelenetek alatt pedig látjuk és halljuk is óket." [61] 
Úgy vélem, Shakespeare oly módon egyesíti a tömeget a test képével, hogy olyan jeleneteket hoz létre, amelyekben a tömeg, majd (legvégül) az egész színpad egy testnek feleltethetô meg, mint ahogy Ford más eszközökkel éri el ugyanezt a hatást a Kár, hogy kurvában. A darab során a kötényszínpad és a színészek olyan helyzeteket teremtenek, melyekben testek csoportjaiba történik behatolás. A nyitójelenet is egy ilyen esetet mutat be: miután a zavargó sokaság összegyúlik, az Elsô polgár maga köré rendeli és megszólítja az embereket. Függetlenül attól, hogy kisebb csoportokban, körökben vagy félkörökben gyúlnek össze a jelenlévôk, az éppen színpadra lépô Meneniusnak a hátulsó részből kell elôrenyomulnia, hogy a kör közepére érkezhessen, amely így körülveszi. Azzal, hogy behatol a tömegbe, megteszi elsô lépését annak uralása és feloszlatása felé. Megjelenésével és a színpad közepének elfoglalásával Menenius a gyomorról elmondott meséjének vizuális emblémáját nyújtja. Ỗ válik a látvány centrumává; alakját pedig üres térnek kell körülvennie, mivel a plebejusok csak akkor láthatják jól, ha megfelelô távolságban állnak tôle. [ ${ }^{62]}$ Mikor Cajus Marcius belép, neki is át kell nyomulnia a plebejusok tömegén, megjelenése azonban megtörheti a kompozíciót: az egyén és tömeg közötti dialógus megszúnhet, és szétszórtabbá, zavarosabbá válhat, ahogy Marcius egyszerre vitázik Meneniussal és a tömeg tagjaival.

Csupán két jelenettel késôbb a be- és kilépés vitatémává is válik, mikor Virgilia kijelenti: „Nem akarok átlépni a küszöbön, míg férjem vissza nem jön a háborúból” (1.3.74-75). Habár Valeria ellenkezik „Ejh, mit zárkóznál így ok nélkül?” (1.3.76), Virgilia hajthatatlan marad elvonulását, elhatárolódását illetôen. Walker úgy véli, Virgilia némaságát, mely önmagában vizuális és emblematikus, fecsegô barátja és anyósa keretezik:

Sosem különül el teljesen az ốt körülvevô nốktôl. Így tehát mikor Virgiliát egy színpadon jelenlévő entitásként kezelem, ez annak a ténynek az elfogadásával történik, hogy Volumnia és Valeria kiemelt jelentôséggel bírnak Virgilia jelenlévôségének hangsúlyozásában; emiatt fenomenológiai értelemben elválaszthatatlanok tôle. [63] A zárt kör még ebben a jelenetben is többször megtörik: Volumnia és Virgilia belépése során figyelmünk nem a behatolás folyamatára, hanem a két nô párosára fókuszál. A színpadi utasítások szerint azonban (melyekrôl a nagy múltú Greg és a kortárs Werstine egyaránt úgy vélik, hogy maga Shakespeare által íródtak) Volumnia és Virgilia leülnek, csendben varrogatnak; a meghittséget és a közösség érzetét Volumnia szavai törik meg: „Kérlek, leányom, énekelj vagy beszélj vidámabban" (1.3.1-2). A kört legközelebb egy Valeria érkezését bejelentô szolga zavarja meg, amikor nagy nehezen sikerül megakadályozni, hogy Virgilia elhagyja a színt. Amikor Valeria feltûnik egy szobalánnyal és egy társalkodónôvel (aki feltehetôleg a nố szolgája), az elôzô meghittség megtörik a színpadot elfoglaló túl sok test jelenlététól.

A következő jelenetben a színpadi tér érzete a fentiekhez képest megfordul; az elsô felvonás negyedik színében a rómaiak Corioli ellen intézett támadását láthatjuk. A fố színészeken túl a színpadi utasítások is ezt jelzik: „Jönnek dobokkal és zászlókkal, Marcius, Titus Lartius, Tisztek, 
Katonák; hozzájok egy Követ.” A volszk hadsereg, mely néhány pillanat múlva kiáramlik az öltözôbőll, még jobban összezavarja a vizuális kompozíciót. Legyốzik a rómaiakat, akik „visszaveretnek sáncaikhoz”. Eztán Marcius túnik föl, átkozódva, s végül kikergeti a volszkokat Corioli kapuján (amit az öltözô ajtaja helyettesít), majd utánuk megy. Miután a kapu bezárul, Titus Lartius római tábornok Marcius elvesztése miatt aggodalmaskodik; a szereplôk és a közönség is csak találgathat, mi folyik „Corioliban” az ajtó mögött. Marcius behatolást végrehajtó erejét a közönség nem akkor látja leginkább, amikor a színpadon küzd, hanem most, amikor nincs jelen, és minden szem arra az ajtóra szegezôdik, ahol eltûnt. Figyelmünk érdekes módon nem az ajtó mögötti, kardok által átszúrt testekre irányul, hanem magára Corioli városára, melybe Marcius belépésével behatolt. A város így azoknak az egyedi testeknek a metaforájává válik, melyeket Marcius a csata során megvág, megsebez és felnyit. Ahogy azt egy másik írásomban bemutatom, a sebból folyó vér által jelzett behatolás szégyenteljes, hiszen a férfi sebezhetôségét tükrözi - azt a sebezhetôséget, amely - Gail Paster szerint - a nôi menstruációval hozható összefüggésbe. ${ }^{[64]}$ Mikor Marcius újra feltúnik, „véresen, s elleneitôl megtámadva” (1.4.61 s.d.), Titus Lartius tábornok felkiált: „Ez Marcius! / Mentsük meg ôt vagy haljunk meg vele”, s a római katonák Marcius felé sietnek, aki megfordul és visszavezeti óket a városba (1.4.61-62). Ez a cselekmény átalakítja azt az értelmezést, miszerint a színpad egy olyan terület, amelybe be lehet hatolni; ehelyett a nézók figyelmét arra az egyetlen pontra irányítja, ahol a kijárat vagy a bejárat megvalósulhat. A behatolás kifelé tud megvalósulni - az öltözôajtón keresztül - mégis távol kerül a közönségtôl. Így amikor Titus Lartius megjelenik, az utánpótlás megáll a kapu elôtt, melyen keresztül Marcius távozott. Amikor visszatér, megfordul s az emberek követik; így a tömeg hirtelen egy emberként nyomul az egyetlen, központi ajtó felé, a színpad pedig kiürül, mintha evakuálták volna. Feltételezésem szerint ez olyan érzést kelthet a nézóben, mintha a tér egyszerre megduzzadna, majd lelohadna nem szó szerinti értelemben, hanem úgy, ahogyan a közönség a színpad terét megtapasztalja. ${ }^{[65]}$ A pódiumon mozgolódó sokaság a kapu mögötti eseményekre fókuszál, s ez azt eredményezi, hogy a közönség nem csak arra figyelhet, amit az ajtók elrejtenek, hanem a cselekmény megszakadását hirtelen lelassulásként élheti meg - a nézók akár olyannak is érezhetik, mint amikor az erekben hirtelen megfagy a vér. Érzékelhetik a színpad „lelohadását” úgy, mint hirtelen kiüresedést, a feszültség hiányát a közvetlen közelben, és mint a jelenet lezárását; ez utóbbit sugallja a kiáramlás, ami - egy alapvetố értelmezés szerint - a rómaiak elkerülhetetlen gyôzelmét hordozza magában.

Ha építészeti szempontból közelítjük meg, ennek a jelenetnek a színrevitele a térben való lét két eltérô felfogását valósítja meg. Edward S. Casey két szélsôséges építészeti tapasztalatot különít el: a „hesztiait” és a „hermetikusat”. Szerinte „bármelyik épület, mely a hesztiai térfoglalást részesíti elônyben... általában központosított és önmagába zárt terület. Az implicit irányultság a középpontból a periféria felé tart, betartva azt az építészeti szabályt, miszerint "a belsô elrendezést kifelé kell terjeszteni “” [66] Ezzel szemben a „hermetikus térfoglalás határozottan mozdul ki”; „egy távoli, mozgó pozíciót reprezentál." [67] Shakespeare mindkét megoldást felkínálja nézôinek az elôzô jelenetben vizsgált proxemika által; az élmény mindkét formája zsigerileg hat a közönségre, 
és egy olyan énérzékelést hoz létre, mely lényegesen eltér attól, amit „a szemek között vagy mögött tapasztalunk." [68]

A test színrevitele meghatározó a nézôi tapasztalás szempontjából. Habár kapcsolódik a proxemika területéhez, a be- és kilépések hatása túlmutat ezen az egyszerú dimenzión; nem csak a közelségtôl függ, hanem a színházon belül a színpad berendezésétôl és használatától is. A színpadi tér tehát legyen az kötényszínpad vagy proszcénium - meghatározó szereppel bír a nézôi tapasztalás tekintetében, hiszen minden színpadkép más-más kapcsolatot állít fel a közönség és a cselekmény között.

A koramodern testmetaforák által közvetített énképet nem könnyú meghatározni, hasonlóan ahhoz a szelfhez, amelyet a térbeli tapasztalat hoz létre. A proprioceptikus analízis színpadra való alkalmazásának érvényessége azonban nyilvánvaló. Freud paradigmái olyan mélyen beépültek a kultúránkba, hogy a közönség propriocepciójának legnyilvánvalóbb értelmezése a színpadon látott akció által kiváltott tudatalatti válasz lenne. Ez a felfogás tagadja a tapasztalásnak azt a természetét, mely sem pszichikai szerkezetekhez, sem szellemi aktivitáshoz nem köthetô. Ha úgy tetszik, az egyén, „testisége” a szubjektivitás egyik fontos építőeleme - azé a szubjektivitásé, melyet szélesebb körben kellene értelmezni, mint ahogy azt elôttünk tették.

Azok a tudósok, akik a koramodern nézó tapasztalatáról írtak, intuitív módon gyakran figyelembe vették a színpadon lévố testi vagy akár proprioceptív elemeket. Belsey nem csak a The Subject of Tragedy címú múvében tanulmányozza a psychomachia használatát, az Amalfi hercegnójérôl íródott elemzésében is többször kitér hasonló témákra; a dráma középpontjában a következô kérdés áll: „Ki uralkodik a hercegnố teste felett?”. Amikor Huston Diehl a közönség élményérôl ír, akkor azt a színpadi erôszak kontextusában teszi. ${ }^{[69]}$ Vizsgálódásunkat azonban folytatnunk kell: meg kell néznünk, hogyan alakítják a szubjektumot a térbeli elemek, miközben a drámát egyszerre gondoljuk el mimetikus formaként és a színészek és a közönség tagjai közötti intraperformatív viszonyként. A drámai színház színpadias jellege sajátos elemzési lehetôségét nyújtja az emberi tapasztalás eme dimenziójának.

Fordította Szamosközi Enikő

A fordítást ellenôrizte Matuska Ágnes

A szöveg eredeti megjelenési helye:

Jennifer A. Low: „Bodied Forth: Spectator, Stage and Actor in the Early Modern Theater”. Comparative Drama, 2005, 39.1. 1-29.

\section{Jegyzetek}

1. Az eredeti címben a „bodied forth” kifejezés szerepel, amely - mint a cikkból is kiderül - egyszerre jelent megtestesülést a szelf/identitás és a test viszonyában, de megtestesítést is, abban az értelemben, ahogyan 
egy szerzô vagy a színpadi viszonyok létrehozzák a karaktert - a szerk.

2. A Bussy D'Ambois idézetek forrása: Chapman, George: Bussy D’Ambois. Szerk. Robert J. Lordi. Lincoln, Nebr., Nebraska University Press, 1964. A szöveg a Q2 1641-es kiadásán alapszik. A tanulmányban szereplő idézetek fordítását, beleértve a drámaszövegek prózai fordítását is (amennyiben máshogy nem jelöltek), Sz. E. készítette.

3. Ford. Mészöly Dezsô. A Shakespeare-idézetek magyar forrása: Shakespeare összes múvei. Budapest: Helikon Kiadó, 1992.

4. A Mészöly Dezső fordítás az 5.3.48-ban a következóket írja: „[Romeo] feltöri a kripta ajtaját”. Az 5.3.87-ben a színpadi utasítás így szól: „Párist a kriptába fekteti”. A Q1, azaz az 1-es Quarto ezen kívül még a következôt is meghatározza: „Lôrinc atya megáll, a fegyverekre és a vérre mered”, rögtön mielôtt azt kiáltja „Nagy ég! miféle vér csepegte le / A kriptának kôlépcsôzetét?” (ford. Mészöly Dezsô). Két sorral késôbb a színpadi utasítás a következôt írja: „Belép a kriptába”. A kriptára való megannyi utalás azt sugallja, hogy az építmény fizikailag is meg volt jelenítve a színpadon, mely célnak az öltözóház volt a legmegfelelóbb. Hasonló bizonyítékokra alapozva Gurr azt állítja, hogy a híres erkély-jelenetnél a Capulet-házat is az öltözôház jelölte" (Gurr, Andrew: The Shakespearen Stage, 1574-164. Cambridge, Cambridge University Press, 1992. 182.). [Az öltözóház (tiring house) a színpad végében, az erkély emelvényének függönnyel ellátott alsó része volt - a szerk.]

5. Ezt részben cáfolhatja a Michael Danahy által felvetett vita a hálókamrákról (Danahy, Michael: Social, Sexual, and Human Spaces in La Princess de Cleves. French Forum, 1981. szept., 6. 3. 212-224). Danahy érvelése mégis egyezik az enyémmel: amíg az udvarhölgyeknek nincs privát terük, és még azt sem dönthetik el, hogy kinek van bejárása a hálószobájukba, addig valószínúleg arra sincs lehetôségük, hogy kifejlesszenek magukban egy belsô teret, vagyis egy olyan szelfet hozzanak létre, mely mások utasításaitól és kívánalmaitól különválasztható.

6. Lásd: Gurr, Andrew: The Shakespearen Stage. 160. Gurr rámutat:

7. Gondoljunk csak a hasonló helyszínek „budoár hangulatára” (hogy egy hasznos, de anakronisztikus kifejezéssel éljünk); ilyen például Clerimont öltözôszobája Jonson Epicoene címú múvében, a hercegnô szekrénye Webster Amalfi hercegnójében, vagy Tamyra szobája ebben a müben.

8. Ez a sor valójában a Romeo és Júlia végén megjelenített arany szobrokra utalhatott; azokra, melyek a halott szerelmeseket megörökítették.

9. Freud, Sigmund: Introductory Lectures on Psychoanalisis. Szerk. és ford. James Strachey. New York, Norton, 1966. 156. Magyarul: Bevezetés a pszichoanalizisbe. Ford. Hermann Imre. Budapest, Gondolat, 1986.

10. A koramodern Angliában a halálra vonatkozó kifejezések nem csak az élet beteljesülését jelentették, de (pl. „kis halál”-ként) a korabeli konvenció szerint a szerelmi beteljesülést is megidézték - a szerk.

11. Ubersfeld, Anne: Reading Theatre. Szerk. Paul Perron és Patrick Debbeche. Toronto, University of Toronto Press, 1999. 110.

12. Ezek a szimbolikus szerkezetek Bussy halála után is folytatódnak. Miután szeretôje elesik, Tamyra könyörög, hogy elhagyhassa férje házát. A nônek nem sikerült sem viszonyát, sem a hálószobában történteket titokban tartani s diszkrécióval kezelni; emiatt kéri férjétól, hogy engedje távozni, míg be nem gyógyulnak a késeléstôl származó sebei, amelyekre így utal: „Mit balzsam begyógyítani soha nem fog, / Míg a halál el nem éri, így szeretem e sebeket / melyeket kezed nyitott testemen” (5.4.194-96). Tamyra, akit groteszk módon járt át a férje fallikus kése, megígéri, hogy szeretettel fog sebeire tekinteni, hiszen azt jelzik, hogy csakis a férjének van hatalma teste felett, kizárólagos bejárással rendelkezik, és ezt úgy teheti meg, ahogyan kedve tartja. A nő megfogadja: „Látványommal többé nem szomorítalaktekintetem és az ég közé nem ékelôdik többé mennyezet; a végtelen sivatagba / mint egy üldözött nôsténytigris / 
Elmenekülök (5.4.197-200). Mint egy üres héjat, úgy hagyja hátra Tamyra azt a helyet, mely képtelen volt számára biztonságot nyújtani, és ehelyett a pőreséget, a vadon ígéretét keresi. Bussy halála után a nônek nincs szüksége személyes, privát térre többé. Miután férje megkéselte ôt és megölte szeretôjét, Tamyra élő példájává válik azoknak az asszonyoknak, akinek nincs titkolnivalójuk, hiszen belsô énjük a sivárságon kívül nem rejt mást; a nő pedig ez hajlandó megosztani az egész világgal.

13. Belsey, Catherine: The Subject of Tragedy: Identity and Difference in Renaissance Drama. London, Methuen, 1985. Michael Hattaway a berchti gest kifejezést használja azoknak a pillanatoknak a jellemzésére, mikor „a jelenet látványelemei összhangban vannak a dialógussal, felfedve így az élet drámában ábrázolt jellemzőit." (Hattaway, Michael: Elizabethan Popular Theatre: Plays in Performance. London, Routledge, 1982. 57.)

14. Belsey, Catherine: Emblem and Antithesis in The Duchess of Malfi. Renaissance Drama, 1980. 11. 117.

15. Példaként az Oxford English Dictionary Edward Hall Krónikáját idézi a III. Richárdból, ahol a Wales-

16. Puttenham, George: The Arte of English Poesie. Kent, Ohio, Kent State University Press, 1970. 159.

17. Gail Kern Paster korszakalkotó múvét követve (The Body Embarrassed: Drama and the Disciplines of Shame in Early Modern England. Ithaca, Cornell University Press, 1993.) sok szerző tanulmányozta a szelf és a testnedvek koramodern elmélete közötti kapcsolatot. Megközelítésemben a konkrét, fizikai érzékelésre fókuszálok, és kevésbé foglalkozom a kor fiziológiai vitáival.

18. Belsey: The Subject of Tragedy. 14.

19. Paster: The Body Embarassed. 3.

20. Lefebvre, Henri: The Production of Space. Ford. Donald Nicholson-Smith. Oxford, Blackwell, 1991.1.

21. Lefebvre, Henri: i.m.

22. Marshall, Cynthia: The Shattering of the Self: Violence, Subjectivity, and Early Modern Texts. Baltimore, Johnson Hopkins University Press, 2002. 14.

23. Paster: The Body Embarrassed. 3.

24. Huston, Hollis: The Actor's Instrument: Body, Theory, Stage. Ann Arbor: University of Michigan Press, 1992. 112. A témával kapcsolatban lásd meg: Hall, Edward T.: The Hidden Dimension. Garden City, New York, 1966. Magyarul: Rejtett dimenziók. Ford. Falvay Mihály. Budapest, Gondolat, 1980. Az idézetek magyar forrását a harmadik kiadás alapján közöljük (Budapest, Katalizátor Iroda, 1995). Hall a különbözó kultúrákat vizsgálja többek között Európában (123-38), Japánban (139-44) és a Közel-Keleten (167-177).

25. Bourdieu, Pierre: Outline of a Theory of Practice. Cambridge, Cambridge University Press, 1977. 94. Magyarul: A gyakorlat elméletének vázlata. Ford. Sebes Anna. Budapest, Napvilág Kiadó, 2009. 248.

26. Kelso, Ruth: Doctrine for the Lady of the Renaissance. Urbana, Ill., University of Illinois Press, 1956. 43-44.

27. Family, Sex, and Marriage in England, 1500-1800 címú könyvében (New York, Harper, 1977) Lawrence Stone Lady Jane Grey-t idézi, ahogy a nô szüleinek szigorú és meglehetôsen rosszindulatú nevelésérôl panaszkodik:

28. Low, Jennifer A.: Manhood and the Duel: Masculinity in Early Modern Drama and Culture. New York, Palgrave, 2003. 73-74.

29. Hall: Rejtett dimenziók. 121.

30. Az 1.1.25-27-ben Giovanni megkérdezi a Pátertôl, „hát egy nyafka szó... ez válasszon el / Örök boldogságomtól?" (ford. Vas István). Mivel boldogságát Annabella testének élvezése nyújtja számára, a „fivér-nóvér" szavakra válaszvonalként való utalás arra enged következtetni, hogy Giovanni szobaként tekint nôvére testére, melyet elzár elóle a vérfertôzést, testvérszerelmet tiltó konvenció. Késôbb, mikor a férfi tudomást szerez Annabella terhességérôl, rémülten kérdezi meg Putanát „De most milyen az 
állapota?" (3.3.17.) A sor angol verziója ("But in what case is she?") tárolóeszközként referál Annabella testére; azonban ebben a kontextusban a nô nem üres tartály, mely arra vár, hogy a férfi fallosza megtöltse, hiszen a születendô gyermek jelenléte már magában hordozza ezt a telítettséget, amely annak az eredménye, hogy Giovanni korábban „megtöltötte” Annabellát.

31. Minden Kár, hogy kurva idézet forrása: Ford, John: Kár, hogy ká. Ford. Vas István. Budapest, Európa Könyvkiadó, 1984. Az angol szövegben idézett kiadás a Ford által is jóváhagyott Q1 verziót vette alapul.

32. Ellenpólusként vö. John Webster Amalfi hercegnô címú drámájának következô jelenetével. Ferdinand belép a hercegnố szobájába, pont, amikor a nô így szól Antonióhoz: „Van miért szeress: én szívem megnyitottam / Neked” (Webster, John: The Duchess of Malfi. Szerk. Elizabeth Brennan. New York, Norton, 1993. 3.2.61. Magyarul: Amalfi hercegnó. Ford. Vas István. In: Angol reneszánsz drámák: Shakespeare kortársai. II. kötet. Szerk. Szenczi Miklós. Budapest: Európa Könyvkiadó, 1961, 328.) Judith Haber a következő megjegyzést füzte a jelenethez: „Mikor Ferdinand belép, hívatlanul s »láthatatlanul«, erôszakosan visszafoglalja a nô testét/szobáját/a színpadot, és tárolóedényének nevezi az üres, passzív edényt, amely létének alapja... Ennél a pontnál a hercegnô beszéde, érthetô módon, radikálisan megváltozik." (Haber, Judith: 'My Body Bestow upon my Women': The Space of the Feminine in The Duchess of Malfi. Renaissance Drama, 1997, 28, 144.) Georgianna Ziegler folytatja az érvelést a Cymbeline-rôl szóló tanulmányában: „Iachimo számára egy nô teste a hálószobájának részét képezi, s így mindkettő határai megsérthetőek”. Ugyan Iachimo nem tesz fizikai erôszakot Imogenen, a nézó úgy érezheti, hogy a férfi voyeurisztikus tekintetének behatolásával az erószak mégis megtörtént.” (Ziegler, Georgianna: My Lady's Chamber: Female Space, Female Chastity in Shakespeare. Textual Practice, 1990, 4. 1. sz. 82.)

33. Fumerton, Patricia: Cultural Aesthetics: Renaissance Literature and the Practice of School Ornament. Chicago, Chicago University Press, 1991. 69.

34. A Kár, hogy kurva angol verziójának szerkesztője, N.W. Bawcutt a következôt jegyzi meg: „A quartó kiadásban található megjegyzés, amely szerint a jelenet a Páter szobájában játszódik, nyilvánvaló tévedés, hiszen a jelenetben Annabella szobájában vagyunk (lásd 3.4.33)" ('Tis Pity She's a Whore, 57.). Az idézett sorban Florio így szól a Páterhez: „A szobájához vezetem, atyám” (ford. Vas István) [ahol az angolban a nônemú névmás jelzi, hogy Annabella szobájáról van szó]. A Kár, hogy kurva idézetek angol verziójának forrása: Ford, John: 'Tis Pity She's a Whore. Szerk. N.W. Bawcutt. Lincoln, Nebraska, University of Nebraska Press, 1966.

35. Mark Stavig szerkesztô szerint a Páter beszéde Ford Christ's Bloody Sweat címú versén alapszik. Lásd Stevig bevezetését a 'Tis Pity She's a Whore által szerkesztett kiadásában. (Arlington Heights, Illinois, AHM, 1966. vii-xix)

36. Claudine Defaye ezt a jelenetet pszichológiai keretként értelmezi, melyból a Páter jelenléte nyújt kiutat:

37. A jelenet szinte teljesen biztosan a Soranzo házában lévő legnagyobb hálókamrában játszódik.

38. Maus, Katharine Eisaman: Inwardness and Theatre in the English Renaissance. Chicago, University of Chicago Press, 1995. 4.

39. Sok kritikus kísérelte meg tisztázni a Giovanni szenzációhajhász mozdulatai mögött rejlô személyes szimbolikát; köztük Ronald Huebert is, aki szerint ezek a gesztusok egy hibás analógiát jelenítenek meg egy titok felfedése és a mellkas feltárása között (Huebert, Ronald: John Ford, Baroque English Dramatist. Montreal, McGiill-Queen's University Press, 1977. 145), vagy Michael Neill, akinek véleménye több ponton találkozik az enyémmel, amikor megpróbálja rendszerezni azokat az egymással versengó definíciókat és magyarázatokat, melyeket [Giovanni mozdulata] megenged (Neill, Michael: 'What Strange Riddle's This?': Deciphering 'Tis Pity She's a Whore. In John Ford: Critical Re-Visions. Szerk. Michael Neill. Cambridge, Cambridge University Press, 1988. 165). Wiseman úgy látja, Giovanni számára Annabella szíve „a 
vérfertôzés minden személyes és zavarba ejtô jelentését magába sûríti"('Tis Pity She's a Whore:

Representing the Incestuous Body. In Revenge Tragedy. Szerk. Stevie Simkin. New York, Palgrave, 2001. 222). Wiseman azonban - legyenek bármilyen jó meglátásai - olyan metaforát használ a térkoncepciók leírására, mely teljesen szembemegy célommal, hogy rámutassak, miképp formálta a tér az emberi tudatot és vice versa. Ami még ennél is szembetûnőbb: Wiseman érvelése mintha Ford retorikáját követné, amikor azt állítja, hogy „a nôi test etikai, financiális, spirituális, érzéki és pszichológiai területként van ábrázolva” a Kár, hogy kurvában, és hogy Annabella teste „folyamatosan újraértelmeződik az így egymással versengô interpretációs lehetôségek által” (215). Wiseman azonban hozzám hasonlóan úgy látja, hogy „Annabella testének jelentôségét folyamatosan változtatják a darab során a különbözô, ôt leíró diskurzusok" (216).

40. Ziegler: My Lady's Chamber. 80.

41. Huston: The Actor's Instrument. 113.

42. Gosson, Stephen: Playes Confuted in Five Actions. 1582; reprint, New York, Garland, 1972. B8v.

43. Stubbes, Phillip: The Anatomie of Abuses. 1573; reprint, New York, Garland, 1973. A Preface to the Reader, idézet In Marshall: The Shattering of the Self. 17.

44. Hall: i.m. 55 .

45. Smith, Bruce R.: The Acoustic World of Early Modern England: Attending to the O-Factor. Chicago, Chicago University Press, 1999. 206.

46. Hall: i.m.. 138.

47. Hall: i.m. 138-9.

48. Az eredetiben a „groundlings” szó szerepel, amely a színpad elôtti térre olcsó állójeggyel bejutott nézôkre utal. A koramodern közszínházakban a (drágább) ülöhelyek a színházépület színpadot körbefogó karéjában helyezkedtek el, így a színpadtól általában távolabbra kerültek. A szerk.

49. Hall: i.m. 135.

50. Hall: i.m. 135 .

51. Weimann, Robert: Shakespeare and the Popular Tradition in the Theater: Studies in the Social Dimension of the Dramatic Form and Function. Baltimore, Hopkins University Press, 1978. 83.

52. Ahogyan Gay McAuley megjegyzi:

53. Gurr: The Shakespearean Stage. 179.

54. Cynthia Marshall utal erre a témára a „Wound-man: Coriolanus, Gender, and the Theatrical Construction of Interiority" címú cikkében. (In Feminist Readings of Early Modern Culture. Szerk. Valerie Traub, M. Lindsay Kaplan és Dympna Callaghan. Cambrdige, Cambrdige University Press, 1966. 95.

55. A penetráció természetesen nem a legmegfelelőbb kifejezés. Jarrett Walker hasznos magyarázattal szolgál: „[Coriolanus] nem tud különbséget tenni aközött, amikor etetik, és amikor megsebesítik. Mindkét forma bekebelezésen alapszik, melyekre azzal válaszol, hogy gondolkodás nélkül „visszaköp” a világra, a befogadás kényszeres tagadásával." (Walker, Jarrett: Voiceless Bodies and Bodiless Voices: The Drama of Human Perception in Coriolanus. SQ, 1992. nyár, 43. 2. sz. 176.) Ezek a terminusok - meglátásom szerint lehetôvé teszik számunkra, hogy még pontosabban érzékeljük, milyen folyamatok dolgoznak a darabban. Az emésztést indikáló éhezés is egy idekapcsolódó kifejezés, melyet Stanley Cavell úttörô tanulmányának középpontjába helyez, lásd 'Who does the wolf love?' Coriolanus and the Interpretation of Politics (In Shakespeare and the Question of Theory. Szerk. Patricia Parker és Geoffrey Hartman. New York, Routledge, 1985. 245-72).

56. A darabból való idézetek magyar változatát Petôfi Sándor fordításában közöljük. 
57. Shakespeare: i.m. 95.

58. Walker, Jarrett: Voiceless Bodies and Bodiless Voices. 172.

59. 1603-tól Shakespeare társulata - a szerk.

60. A csoportok által megtapasztalt terekkel kapcsolatban Yi-Fu Tuan úgy véli, a tömeg jelenléte „nem feltétlenül csökkenti, inkább felerôsíti az események jelentőségét; a tömegben lévô emberek nem feltétlenül érzik azt, hogy el vannak nyomva a térben" akkor, ha azonos okból vannak jelen, és nem ellenzik a többiek jelenlétét. (Tuan, Yi-Fu: Space and Place: A Humanist Perspective. In Philosophy in Geography. Szerk. Stephen Gale és Gunnar Olsson. Dordrecht, D. Reidel, 1979. 404.)

61. Jagendorf, Zvi: Coriolanus: Body Politic and Private Parts. SQ, 1990. tél, 41, 4. sz. 462. Hasonlóan vélekedik Arthur Riss is, aki szerint a darab „létrehoz egy kapcsolatot vidék és test között”, ezáltal „összhangot teremtve a nyilvános terek bekerítésének igénye között, és Coriolanus vágya között, amely testének lezárására irányul” (Coriolanus and the Revolt Language. ELH, 1992. tavasz, 59, 1. sz. 55).

62. Jagendorf: i.m. 462. Más véleményen van Ralph Berry, aki a nyitójelenet elemzése után azt a következtetést vonja le, hogy „a látszattal ellentétben a római tömeg nem a nép elsöprô akaratának manifesztációja [...] nem látni olyan rettentô szeszélyt, olyan iszonyú vérszomjat, mint Antonius felemelkedésekor a Fórum jelenetben. Ezzel szemben meghatározhatatlan és változó jellemzók halmazát látjuk. (Casting the Crowd: Coriolanus in Performance. Assaph C4, 1988. 144.)

63. A jelenet alternatív értelmezése lehetne az, hogy az Elsô és Második polgár közötti párbeszéd a színpad centrumában zajlik, a tömeggel körülvéve. Ez a beállítás egy szúk, intim teret képezne, mely Menenius belépése által megtörhet vagy feloldódhat, ahogy a két polgárt végül elnyeli a tömeg. Michael Warren több színreviteli lehetőséget is számba vesz a jelenettel kapcsolatban The Perception of Error: The Editing and Performance of the Opening of 'Coriolanus' címú cikkében. (In Textual Performances: The Modern Reproduction os Shakespeare’s Drama. Szerk. Lukas Erne és Margaret Jane Kidnie. Cambridge, Cambridge University Press, 2004. 127-42.)

64. Walker: Voiceless Bodies and Bodiless Voices. 179, 16-os lábjegyzet.

65. Paster: The Body Embarrasssed. 92.

66. Janet Adelman mélyen egyetért ezzel a meglátással, bár nem izgatja a színrevitel, és pszichoanalitikus megközelítéssel dolgozik:

67. Casey, Edward S.: Getting back into Place: Toward a Renewed Understanding of the Place-World. Bloomington, Indiana University Press, 1993. 133.

68. Casey: i.m. 137-38.

69. Edward Casey gondolatai az „ittlévôségról”: „Még saját hús-vér testemen belül is meg tudom különböztetni a testileg lokalizálható »ittlévôséget« attól az itt-tôl, amely a testemmel mint egésszel egybeesik. Ebben az értelmezésben az »ittlévőségem «” a fejemmel, még pontosabban a szemeim közötti vagy azok mögötti régióval azonosítható.” (Getting Back into Place. 52.)

70. Lásd: Belsey: The Subject of Tragedy: identity and Difference in Renaissance Drama; Belsey: Emblem and Antithesis in The Duchess of Malfi. 115-34; és Diehl: The Iconography of Violence in English Renaissance Tragedy. Renaissance Drama, 1980/11. 27-44.

\section{Irodalomjegyzék}

- Adelman, Janet: „Anger's My Meat”: Feeding, Dependency, and Aggression in Coriolanus. In Representing Shakespeare: New Psychoanalytic Essays. Szerk. Murray M. Schwartz and Coppelia 
Kahn. Baltimore, Johnson Hopkins University Press, 1980.

- Belsey, Catherine: Emblem and Antithesis in The Duchess of Malfi. Renaissance Drama, 1980. 11.

- Belsey, Catherine: The Subject of Tragedy: Identity and Difference in Renaissance Drama. London, Methuen, 1985.

- Berry, Ralph: Casting the Crowd: Coriolanus in Performance. Assaph C4, 1988.

- Bourdieu, Pierre: Outline of a Theory of Practice. Cambridge, Cambridge University Press, 1977. 94. Magyarul: A gyakorlat elméletének vázlata. Ford. Sebes Anna. Budapest, Napvilág Kiadó, 2009.

- Casey, Edward S.: Getting back into Place: Toward a Renewed Understanding of the Place-World. Bloomington, Indiana University Press, 1993.

- Cavell, Stanley: 'Who does the wolf love?' Coriolanus and the Interpretation of Politics. In Shakespeare and the Question of Theory. Szerk. Patricia Parker és Geoffrey Hartman. New York, Routledge, 1985. 245-272.

- Chapman, George: Bussy D’Ambois. Szerk. Robert J. Lordi. Lincoln, Nebr., Nebraska University Press, Shakespeare összes müvei. Budapest: Helikon Kiadó, 1992.

- Danahy, Michael: Social, Sexual, and Human Spaces in La Princess de Cleves. French Forum, 1981. szept., 6. 3. 212-224

- Defaye, Christine: Annabella's Unborn Baby: The Heart of the Womb in 'Tis Pity She's a Whore. Cahiers élisabéthains, 1979, 15.

- Diehl, Huston: The Iconography of Violence in English Renaissance Tragedy. Renaissance Drama, 1980/11. 27-44.

- Ford, John: 'Tis Pity She's a Whore. Szerk. N.W. Bawcutt. Lincoln, Nebraska, University of Nebraska Press, 1966. Magyarul: Kár, hogy ká. Ford. Vas István. Budapest, Európa Könyvkiadó, 1984.

- Freud, Sigmund: Introductory Lectures on Psychoanalisis. Szerk. és ford. James Strachey. New York, Norton, 1966. 156. Bevezetés a pszichoanalizisbe. Ford. Hermann Imre. Budapest, Gondolat, 1986.

- Fumerton, Patricia: Cultural Aesthetics: Renaissance Literature and the Practice of School Ornament. Chicago, Chicago University Press, 1991.

- Gosson, Stephen: Playes Confuted in Five Actions. 1582; reprint, New York, Garland, 1972.

- Gurr, Andrew: The Shakespearen Stage, 1574-164. Cambridge, Cambridge University Press, 1992.

- Haber, Judith: 'My Body Bestow upon my Women': The Space of the Feminine in The Duchess of Malfi. Renaissance Drama, 1997.

- Hall, Edward T.: The Hidden Dimension. Garden City, New York, 1966. Magyarul: Rejtett dimenziók. Ford. Falvay Mihály. Budapest, Gondolat, 1980.

- Hattaway, Michael: Elizabethan Popular Theatre: Plays in Performance. London, Routledge, 1982.

- Huebert, Ronald: John Ford, Baroque English Dramatist. Montreal, McGiill-Queen's University Press, 1977.

- Huston, Hollis: The Actor's Instrument: Body, Theory, Stage. Ann Arbor: University of Michigan Press, 1992.

- Jagendorf, Zvi: Coriolanus: Body Politic and Private Parts. SQ, 1990. tél, 41, 4.

- Kelso, Ruth: Doctrine for the Lady of the Renaissance. Urbana, Ill., University of Illinois Press, 1956. 43-44.

- Lefebvre, Henri: The Production of Space. Ford. Donald Nicholson-Smith. Oxford, Blackwell, 
1991.

- Low, Jennifer A.: Manhood and the Duel: Masculinity in Early Modern Drama and Culture. New York, Palgrave, 2003.

- Marshall Cynthia: „Wound-man: Coriolanus, Gender, and the Theatrical Construction of Interiority" címú cikkében. In Feminist Readings of Early Modern Culture. Szerk. Valerie Traub, M. Lindsay Kaplan és Dympna Callaghan. Cambrdige, Cambrdige University Press, 1966.

- Marshall, Cynthia: The Shattering of the Self: Violence, Subjectivity, and Early Modern Texts. Baltimore, Johnson Hopkins University Press, 2002.

- Maus, Katharine Eisaman: Inwardness and Theatre in the English Renaissance. Chicago, University of Chicago Press, 1995.

- McAuley, Gay: Space in Performance: Making Meaning in the Theatre. Ann Arbor, University of Michigan Press, 1999.

- Michael Warren: The Perception of Error: The Editing and Performance of the Opening of ' Coriolanus' címú cikkében. In Textual Performances: The Modern Reproduction os Shakespeare's Drama. Szerk. Lukas Erne és Margaret Jane Kidnie. Cambridge, Cambridge University Press, 2004. 127-142.

- Neill, Michael: 'What Strange Riddle's This?': Deciphering 'Tis Pity She's a Whore. In John Ford: Critical Re-Visions. Szerk. Michael Neill. Cambridge, Cambridge University Press, 1988.

- Paster, Gail Kern: The Body Embarrassed: Drama and the Disciplines of Shame in Early Modern England. Ithaca, Cornell University Press, 1993

- Puttenham, George: The Arte of English Poesie. Kent, Ohio, Kent State University Press, 1970.

- Riss, Arthur: Coriolanus and the Revolt Language. ELH, 1992. tavasz, 59.

- Smith, Bruce R.: The Acoustic World of Early Modern England: Attending to the O-Factor. Chicago, Chicago University Press, 1999.

- Stevig, Mark: Ford, John: 'Tis Pity She's a Whore. Bevezetô. Arlington Heights, Illinois, AHM, 1966. vii-xix.

- Stone, Lawrence: Family, Sex, and Marriage in England, 1500-1800 címú könyvében (New York, Harper, 1977

- Stubbes, Phillip: The Anatomie of Abuses. 1573; reprint, New York, Garland, 1973.

- Tuan, Yi-Fu: Space and Place: A Humanist Perspective. In Philosophy in Geography. Szerk. Stephen Gale és Gunnar Olsson. Dordrecht, D. Reidel, 1979.

- Ubersfeld, Anne: Reading Theatre. Szerk. Paul Perron és Patrick Debbeche. Toronto, University of Toronto Press, 1999.

- Walker, Jarrett: Voiceless Bodies and Bodiless Voices: The Drama of Human Perception in Coriolanus. SQ, 1992. nyár, 43. 2.

- Webster, John: The Duchess of Malfi. Szerk. Elizabeth Brennan. New York, Norton, 1993. Magyarul: Amalfi hercegnô. Ford. Vas István. In: Angol reneszánsz drámák: Shakespeare kortársai. II. kötet. Szerk. Szenczi Miklós. Budapest: Európa Könyvkiadó, 1961.

- Weimann, Robert: Shakespeare and the Popular Tradition in the Theater: Studies in the Social Dimension of the Dramatic Form and Function. Baltimore, Hopkins University Press, 1978.

- Wiseman, S.J: 'Tis Pity She's a Whore: Representing the Incestuous Body. In Revenge Tragedy. Szerk. Stevie Simkin. New York, Palgrave, 2001. 
- Ziegler, Georgianna: My Lady's Chamber: Female Space, Female Chastity in Shakespeare. Textual Practice, 1990, 4. 1. sz. 
(c) Apertúra, 2017. nyár | www.apertura.hu

webcím: https://www.apertura.hu/2017/nyar/low-megtestesules-es-megtestesites-nezo-szinpad-es-

szinesz-a-koramodern-szinhazban/

https://doi.org/10.31176/apertura.2017.12.4.2

(Q)opertúro 